\title{
Understanding Lockups: Effects in Bankruptcy and the Market for Corporate Control
}

\section{Kermit Roosevelt III ${ }^{\dagger}$}

This Article examines the effects of lockups in the market for corporate control and bankruptcy. Developments in the analysis of lockups in the market for corporate control have provided prescriptions that are accurate from either an ex ante or ex post perspective. This Article employs auction theory to articulate a synthesis of the current theory that is satisfactory from both perspectives. Theory addressing lockups in bankruptcy is unsatisfactory from both an ex ante and ex post context. By delineating the crucial differences between bankruptcy and the market for corporate control, this Article develops appropriate standards for governing lockups in bankruptcy.

Introduction 94

I. An Intellectual History of Lockups 97

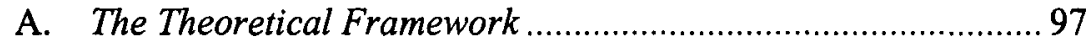

B. The First Generation of Theory ................................................... 101

C. The Revisionists: Ayres and Fraidin \& Hanson ...................... 103

D. The Reactionaries: Kahan \& Klausner................................... 107

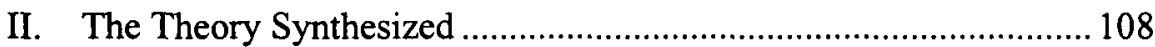

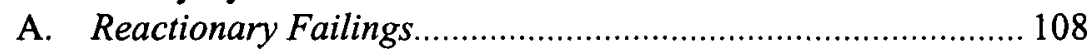

B. Auction Theory Applied ......................................................... 110

1. Common Value Auctions.................................................. 111

2. Independent Private Value Auctions................................117

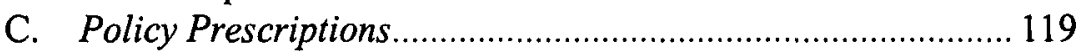

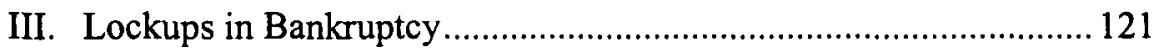

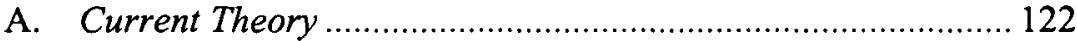

B. The Case Against Lockups ...................................................... 123

1. Creditors Bear Costs Directly ........................................... 124

2. Lockups Are Not Needed To Attract Bidders................... 125

3. Management Opportunism Is More

Threatening .................................................................... 126

4. Bankruptcy Purchases Are a Bargain................................ 128

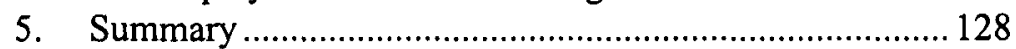

C. Lockups in Bankruptcy Sales of Assets ................................. 128

$\dagger \quad$ Senior Research Scholar, Yale Law School; Resident Fellow, Information Society Project. A.B., Harvard College 1993; J.D., Yale Law School 1997. I thank Henry Hansmann, Douglas G. Lichtman, Alan Schwartz, and Stephen F. Williams for helpful comments and suggestions. All faults are mine. 
D. Lockups and Takeovers Within Chapter 11..........................129

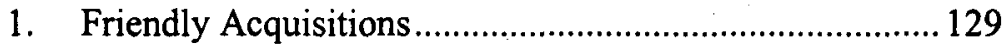

2. Hostile Acquisitions ........................................................ 130

3. Policy Prescriptions ..........................................................131

E. Lockups and a Chapter 11 Auction Alternative...................... 132

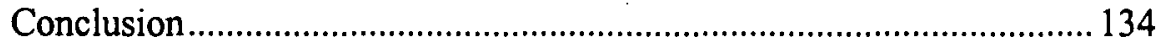

Introduction

Nineteen ninety-eight was a banner year for mergers and acquisitions. The dollar value of such corporate combinations doubled from the preceding year, exceeding two trillion dollars and reaching twenty percent of the gross national product. ${ }^{1}$ Thus, an investigation of the law governing the devices used in the market for corporate control is particularly timely. But the economy; like history (or a washing machine; pick your metaphor), runs in cycles. When the high tide recedes, it will undoubtedly leave many businesses stranded on the beach, and bankruptcy filings will increase. The law governing bankruptcy practice is also ripe for consideration, or soon will be.

Bankruptcy and mergers and acquisitions may seem quite distinct areas of corporate activity, but they raise some common questions. In particular, both demand that courts settle the appropriate treatment of lockups. The term "lockup" encompasses a variety of different devices sharing a common purpose. This Article will distinguish between different types of lockups where necessary, but the different types have similar effects and, for most of the analysis, an understanding of the purpose suffices. As a loose definition, a lockup is a device by which target management promises to compensate a bidder if the proposed merger falls through. Lockups may take a variety of forms: cash breakup fees which are paid to a would-be acquirer if another bid is ultimately accepted; options on treasury stock with an exercise price set near the bidder's offer price; or "crown jewels" options on a desirable portion of the target's assets. ${ }^{2}$ Such agreements obviously play an important role in contests for corporate control. They are, at least on the conventional understanding, a means by which target management can favor a particular bidder, increasing the odds that the target company will end up in the hands of a friendly, rather than a hostile, suitor. ${ }^{3}$ But lockups have a range of uses broader than the standard merger context. They can be employed in any type of sale; a seller may always offer a bidder some compensation if the

\footnotetext{
1 See Charles Weller, Antitrust, NAT'L L.J., Aug. 24, 1998, at B6.

2 See Stephen Fraidin \& Jon D. Hanson, Toward Unlocking Lockups, 103 YALE L.J. 1739, 1747 (1994).

3 As Part I.C discusses, this view is oversimplified, if not flatly incorrect. 
deal is not consummated. ${ }^{4}$ Consequently, lockups also feature quite prominently in the bankruptcy context, where insolvent firms sell off assets, engage in friendly mergers, and are sometimes the targets of hostile acquisitions. $^{5}$

The first and second parts of this Article address the effects of lockups in the market for corporate control. This is relatively well-trodden ground: following a seminal article by Ian Ayres, ${ }^{6}$ a number of scholars have recently bestowed their attention on the lockup. ${ }^{7}$ The theoretical view of lockups in the market for corporate control has passed through several distinct phases; Part I of this Article outlines the dialectical development of that theory. The first generation, still dominant in the Delaware courts, ${ }^{8}$ reasoned that lockups typically allow target management to pursue its own interests at the expense of target shareholders. ${ }^{9}$ First generation scholars thus called for severe judicial scrutiny or outright bans of lockups. Revisionist scholars attempted to demonstrate that these concerns were overstated or even illusory, and demanded greater judicial deference. ${ }^{10}$ Finally, the most recent scholarship argues for the reinstatement of the

4 Granting a lockup to a potential buyer of course makes little sense if the sale does not have the characteristics of an auction, since it is only in an auction-type sale that there exists a serious threat that the seller cannot simply pick the buyer. The Williams Act, Pub. L. No. 90-439, 82 Stat. 454 (1968) (codified as amended at 15 U.S.C. $\S \S 78 \mathrm{~m}(\mathrm{~d})-(\mathrm{f}), 78 \mathrm{n}(\mathrm{d})-(\mathrm{f})(1994)$ ), the legal regime governing mergers, and the Bankruptcy Code, 11 U.S.C. $\$ \S 101-1330$ (1994), both impose auctionstyle requirements on sales. The SEC, under the authority of the Williams Act, creates a de facto auction regime by imposing a delay which allows other bidders to intervene. See 17 C.F.R. $\$ 240.14 \mathrm{e}$ l(a) (1999). Delaware corporate common law will then require managers not to play favorites among bidders. See Revlon, Inc. v. MacAndrews \& Forbes Holdings, Inc., 506 A.2d 173 (Del. 1986). The Bankruptcy Code requires judicial approval of a sale of assets outside the ordinary course of business. See 11 U.S.C. § 363(b). Approval requires a hearing, creating delay, and will not be forthcoming in the face of a higher bid.

5 For bankruptcy cases evaluating the legality of lockups, see, for example, In re Tiara Motorcoach Corp., 212 B.R. 133 (Bankr. N.D. Ind. 1997); In re Bidermann Indus. U.S.A., Inc., 203 B.R. 547 (Bankr. S.D.N.Y. 1997); In re S.N.A. Nut Co., 186 B.R. 98, 101-02 (Bankr. N.D. Ill. 1995); In re America West Airlines, 166 B.R. 908 (Bankr. D. Ariz. 1994).

6 Ian Ayres, Analyzing Stock Lock-Ups: Do Target Treasury Sales Foreclose or Facilitate Takeover Auctions?, 90 COLUM. L. REV. 682 (1990).

7 See, e.g., Stephen M. Bainbridge, Exclusive Merger Agreements and Lock-Ups in Negotiated Corporate Acquisitions, 75 MINN. L. REV. 239 (1990); Fraidin \& Hanson, supra note 2; Marcel Kahan \& Michael Klausner, Lockups and the Market for Corporate Control, 48 STAN. L. REV. 1539 (1996); David A. Skeel, Jr., A Reliance Damages Approach to Corporate Lockups, 90 Nw. U. L. Rev. 564 (1996).

8 See, e.g., Paramount Communications Inc. v. QVC Network Inc., 637 A.2d 34 (Del. 1994); Mills Acquisition Co. v. MacMillan, Inc., 559 A.2d 1261 (Del. 1989); Revlon, 506 A.2d at 173. With respect to judicial treatment of lockups in changes of corporate control, this Article focuses on Delaware common law. Because bankruptcy law is federal, the Article considers a broader range of jurisdictions in that context.

9 See Robert C. Clark, Corporate Law $572-73$ (1986); Lucian A. Bebchuk, The Case for Facilitating Competing Tender Offers: A Reply and Extension, 35 STAN. L. REV. 23, 47 (1982); Frank H. Easterbrook \& Daniel R. Fischel, Auctions and Sunk Costs in Tender Offers, 35 STAN. L. REV. 1, 15 (1982); Alan Schwartz, Search Theory and the Tender Offer Auction, 2 J.L. ECON. \& ORG. 229,238 (1986).

10 See, e.g., Ayres, supra note 6; Fraidin \& Hanson, supra note 2. 
earliest views against the claims of the revisionists. ${ }^{.1}$

Part II of this Article moves beyond that scholarship. It demonstrates that the academic analysis to date has not developed an account that deals adequately with both the specific consequences of lockups in individual transactions and the general effects of a rule permitting or prohibiting lockups. The revisionist account is largely correct in its analysis of the effects of lockups in individual transactions (the "ex post" effects) but fails to appreciate the consequences of a permissive rule (the "ex ante" effects). Its conclusion is wrong, but its reasoning largely right. ${ }^{12}$ The most recent account fails to displace the revisionist account but proposes a more desirable rule. Its reasoning is wrong, but its conclusion largely right. Part II evaluates the competing claims and uses auction theory to develop a synthesis that employs accurate reasoning to obtain the correct result. It endeavors to present both the forest and the trees; it combines the insights of its predecessors and presents for the first time what I believe is a picture accurate at both levels. ${ }^{13}$

11 See Kahan \& Klausner, supra note 7.

12 Generally, Fraidin and Hanson are guilty of a sort of analytic virtuosity; with acute insight they draw out a number of beneficial transaction-specific consequences of lockups, but seem not to notice that some of these conflict. with each other and also with the claimed pre-transaction benefits. For example, they write that "[n]o loyal target would grant and no bidder could credibly demand a lockup for investments already made and in identifying and evaluating the target," Fraidin \& Hanson, supra note 2, at 1814 , but "the bidder can expect to receive a lockup in those circumstances in which the target board would like to sell to the bidder." Id. at 1827. It is unclear what would motivate the target board to grant a lockup to this first "desired" bidder, since the result of such a lockup, if a higher-valuing bidder appears and wins the auction, is decreased shareholder revenue, which target boards, as shareholders, want to maximize. Id. at 1804-05. Lockups can increase the profits from searching ("retums to search") in common value auctions, $i d$. at 1827 , but they can also be used to capture the entire surplus of such auctions. $/ d$. at 1829 . The same is roughly true for independent private value auctions. Compare id. at 1828-29 with id. at 1829 (noting that in an independent private value auction "the highest valuing bidder can win the target at some price below the ideal auction price," but that this problem would not arise in a full enforcement regime). The basic problem here is that there is a tension between revenues and returns to search. It is not a zero-sum game, because in at least some circumstances the available surplus can be increased by reducing transaction costs, but the two goals are usually in conflict and cannot be served simultaneously. One effect will predominate, and an ex ante analysis will have to face the fact that lockups are not panaceas.

13 To see the effect of distinguishing between the two leveis, imagine the following scenarios. First, it might be the case that lockups reduce shareholder revenue in individual transactions but increase it on the whole. Suppose that, after an auction is held, management, having identified the highest valuer, proceeds to negotiate with that bidder using the winning bid as a starting point. Returns to shareholders on the transaction will be maximized by this approach; however, bidders may find their retums under such a regime so small as to make search and bidding a bad investment. In this case, the frequency of takeovers would be greatly reduced and shareholders as a class could be worse off, because they would seldom receive takeover premiums. If lockups were permitted, bidders could demand that management in effect bind itself to accept the highest bid. Although shareholders would receive smaller profits in the particular transaction, the disincentive to search would be reduced and shareholders as a class would be better off.

Conversely, it could be that lockups make shareholders better off in the individual case but worse off in general. Suppose that management uses a lockup to induce a second bidder to enter an auction, thereby driving up the price. Revenues to shareholders will be increased, but the reduced return to bidders could drive search below the point optimal from the shareholder perspective.

My purpose here is not to argue for either of these scenarios, both of which will be considered in 
In contrast to the successive generations of theories of lockups in the context of mergers and acquisitions, the academic analysis of lockups in bankruptcy has shown little movement. The current approach to such lockups is emphatic and univocal but strikingly underdeveloped. Two scholarly pieces ${ }^{14}$ represent almost the entirety of the academy's contribution. Both join the first generation's call for increased judicial scrutiny of lockups in bankruptcy, and both have been cited with approval by courts. $^{15}$

Part III of the Article demonstrates that while the mergers and acquisitions literature displays both the correct analysis and the correct prescription - though not in the same article-the dominant bankruptcy analysis features the worst of both worlds. A merger or sale in bankruptcy differs in important ways from its counterpart outside Chapter 11. Sensitive neither to the true ex post effects of lockups nor to the unique ex ante features of bankruptcy, current bankruptcy scholarship deploys faulty reasoning and reaches the wrong result. Analyzing the differences between bankruptcy and the broader market for corporate control, Part III shows that lockups granted by companies in Chapter 11 must be governed by different standards. However, before examining the factors that distinguish bankruptcy from the ordinary mergers and acquisitions context, it is necessary to develop a general understanding of the effects of lockups.

\section{An Intellectual History of Lockups}

\section{A. The Theoretical Framework}

There are two distinct positive perspectives from which to analyze lockups, and two distinct normative criteria by which to evaluate them. The two perspectives are what I have called "ex ante" and "ex post." An ex post perspective looks to the effect of lockups in individual

greater detail later, but simply to note the possibility of conflict between the rule that is best for one party in a particular transaction and the rule that is best for that party in general.

14 See Bruce Markell, The Case Against Breakup Fees in Bankruptcy, 66 AM. BANKR. L.J. 349 (1992); Paul B. Lackey, Note, An Empirical Survey and Proposed Bankruptcy Code Section Concerning the Propriety of Bidding Incentives in a Bankruptcy Sale of Assets, 93 COLUM. L. REv. 720 (1993). Mark Hebbeln has brought economic analysis to bear on breakup fees, urging that they should be upheld. See Mark F. Hebbeln, Note, The Economic Case for Judicial Deference to Break-Up Fee Agreements in Bankruptcy, 13 BANKR. DEV. J. 475 (1997). The note does not, however, represent an application of revisionist scholarship to the bankruptcy context; indeed, it does not discuss any of the merger and acquisition lockup scholarship. Hebbeln's central claim is that breakup fees may induce a first bid. Id. at 492-96. In fact, however, as Part III.C will show, the value of a first-bidder lockup in a bankruptcy sale is that it may prevent a wasteful auction from taking place.

15 See In re S.N.A. Nut Co., 186 B.R. 98, 101-02 (Bankr. N.D. Ill. 1995) (citing Lackey, supra note 14; Markell, supra note 14); In re America W. Airlines, 166 B.R. 908, 912 (Bankr. D. Ariz. 1994) (citing Markell, supra note 14). 
transactions; an ex ante perspective considers the more general consequences of different legal rules. Corporate derivative suits against disloyal directors provide a usefully simple illustration of the distinction. From an ex post perspective, it may be inefficient to pursue such suits. The costs can be substantial, and will likely exceed the expected recovery. ${ }^{16}$ From an ex ante perspective, however, a policy of suing in every case is likely to have a substantial general deterrent effect. Even if each individual suit is inefficient, the policy favoring such suits reduces costs overall. (A similar, if somewhat more trite, example is a merchant's policy of prosecuting all shoplifters.)

With respect to the treatment of lockups, the point is the following: law casts shadows. Legal rules do more than determine the outcome of particular cases; because people know what the outcomes will be, they tailor their actions accordingly. Bidders will behave differently in a world in which lockups are permitted than they would in one in which lockups were forbidden. The attempt to promote particular values through law must consider not only the effects of rules in cases in which they are applied, but also how they shape behavior by lurking in the background. Analysts hoping to develop policy prescriptions, then, must use the ex ante perspective, for it is only by understanding the broader consequences of rules that we may know if they are desirable.

The two evaluative criteria may be termed maximization of target shareholder revenue and maximization of social wealth. The first demands simply that acquisitions take place at the highest attainable price in order to provide the greatest gain to target shareholders. ${ }^{17}$ The second urges that assets be moved to their highest valuing users with a minimum of transaction costs, and may be more simply characterized as the efficiency norm.

These two analytical disjunctions create four possible windows through which to look at lockups. The four possibilities are: (1) ex ante analysis seeking to promote target shareholder revenue; (2) ex ante analysis seeking to promote efficiency; (3) ex post analysis seeking to promote target shareholder revenue; and (4) ex post analysis seeking to promote efficiency. Courts have tended to opt for the third view, combining ex post analysis with promotion of target shareholder revenue. I will suggest that both components of this perspective are mistaken, but they are understandable and indeed all but inevitable, given the judicial role. Courts decide individual cases; thus the ex post orientation is the one presented to them. They often fail to distinguish it from the ex ante, in that they tend to suppose that the rule that reaches the desired result ex post

16 See, e.g., Joy v. North, 692 F.2d 880, 896 (2d Cir. 1982). 1986).

17 See Revlon, Inc. v. MacAndrews \& Forbes Holdings, Inc., 506 A.2d 173, 180 (Del. 
will also do so ex ante. ${ }^{18}$ But if the correct rules for ex ante and ex post maximization of a particular value do not coincide (and Part II will demonstrate that they do not with respect to lockups), the benefits that seemed so tangible on the ex post analysis will prove to be a mirage, disappearing in light of the ex ante effects.

Ex post analysis is, of course, an essential prerequisite to ex ante evaluation. The cumulative effect of a rule permitting a certain tactic cannot be divined without a precise understanding of the effects of that tactic in the individual case. But in the final evaluation, it is the ex ante effects that will be experienced. That is, a merchant that pursues the "inefficient" (from the ex post perspective) policy of prosecuting shoplifters will reap the benefits of deterrence on its bottom line. The judicial ex post perspective, though understandable, is an obvious and serious mistake.

If courts have erred, have commentators gotten it right? My answer will be: not quite. Academics are surely aware of the fallacy of pure ex post analysis, but they are not always as punctiliously observant as they might be. Existing scholarly treatments of lockups differ in the degrees of emphasis they place on ex post and ex ante analysis. Each, I will suggest, misses at least one perspective. One contribution of this Article is to distinguish sharply ex ante from ex post analysis, employing the latter only as the first step toward the former.

This leaves the question of whether the goal that law should pursue is maximization of target shareholder revenue or overall efficiency. The judicial focus on target shareholder revenue is not so clearly mistaken as its ex post perspective. Indeed, it might superficially seem to be demanded by the fundamental axioms of corporate law: if managers are compelled by their duty of loyalty to further shareholder interests, ${ }^{19}$ surely, one might think, they must seek to maximize shareholder revenue in changes of control. That is what the law should require of them. It is, in fact, what the law does require, ${ }^{20}$ but the reasoning underlying this legal regime also makes an ex post/ex ante mistake. It may be the case with respect to

18 Indeed, Joy $v$. North makes precisely this error:

Where the court determines that the likely recoverable damages discounted by the probability of a finding of liability are less than the costs to the corporation in continuing the action, it should dismiss the case. The costs which may properly be taken into account are attorney's fees and other out-of-pocket expenses related to the litigation and time spent by corporate personnel preparing for and participating in the trial.

692 F.2d at 892 . This is a test for whether the action is in the corporation's interest from an ex post perspective; it omits consideration of the deterrent value of suits from the ex ante perspective.

19 See, e.g., Dennis J. Block et al., Defensive Measures in Anticipation of and in Response to Unsolicited Takeover Prosposals, 51 U. MIAMI L. REV. 623, 623-25 (1997) (discussing duty of loyalty).

20 See, e.g., Revlon, 506 A.2d at 182 . Courts are mistaken in thinking that this regime serves target shareholder interests, but they seem quite committed to it. 
lockups (and again, Part II will demonstrate that it is) that target shareholders in general are better served by management action that does not maximize their revenue in individual transactions-as long as all managers take that course of action. ${ }^{21}$ True promotion of target shareholder revenue, then, must look beyond the individual transaction to the general effects of the rule embodied in the transaction.

Of course, acquiring companies usually have shareholders too. Indeed, the same company may find itself either a target or a bidder. Most significantly, most shareholders hold diversified portfolios and are likely to own stock in both bidders and targets. Thus, a serious attempt to promote shareholder welfare in general might simply coincide with the efficiency norm. If the aim is to make all shareholders better off, surely this is achieved by maximizing the value of all publicly held corporations, which requires precisely that corporate assets be moved to their highest valuing users with a minimum of transaction costs. There is also an obvious case to be made that general utilitarian principles of morality lead to the efficiency norm. ${ }^{22}$ Both these assertions are disputable, but efficiency is the desideratum of most corporate scholars, ${ }^{23}$ and this Article will proceed in that vein. ${ }^{24}$

In assessing efficiency ex ante, we must be concerned not only with how lockups affect individual acquisitions, but also with how they affect the incentives to engage in those acquisitions. Searching for an inefficiently managed or undervalued company is costly, and fewer acquisitions will take place if the profits from searching ("returns to search") are reduced. The goal is not only to move assets to their highest valuers with a minimum of transaction costs in the individual acquisition,

21 As we shall see, lockups thus present a situation analytically roughly equivalent to the prisoner's dilemma chestnut of game theory. A group of individuals (target shareholders) face a situation in which all will do better if all (more precisely, all their agents, i.e., management) follow a particular course of action. However, "defectors" can increase their retums by straying from that course of action. The question with such collective action problems is how to prevent defection, and the answer here, we shall see, is to forbid it. Of course, much of our law is devoted to precisely the task of restraining parties from taking actions that would be in their immediate self-interest but the threat of which would prevent collectively beneficial arrangements. For example, contract law holds parties to their promises even when it would be in their immediate self interest to breach or renegotiate, because without the ability to make such binding promises, no one would enter into contracts. Similarly, the Bankruptcy Code prevents creditors from attempting to collect before each other. See 11 U.S.C. $\S 362$ (1994) (automatic stay provision). Without such a rule, an individual creditor might thereby recover the full amount of its claim, but the practice would lead to the dismemberment of debtor firms worth more as going concerns, reducing the return to creditors overall. See Alan Schwartz, A Contract Theory Approach to Business Bankruptcy, 107 Yale L.J. 1807, 1807 (1998).

22 See generally Alan Schwartz, The Fairness of Tender Offer Prices in Utilitarian Theory, 17 J. LEGAL STUD. 165 (1986).

23 See, e.g., Peter Cramton \& Alan Schwartz, Using Auction Theory To Inform Takeover Regulation, 7 J.L. ECON. \& ORG. 27 (1991); Frank Easterbrook \& Daniel Fischel, The Proper Role of a Target's Management in Responding to a Tender Offer, 94 HARV. L. REV. 1161 (1981).

24 Part III will argue that maximizing sale price may be a worthy goal in the bankruptcy context, but the point of the argument is that higher sale prices promote efficiency related values. 
but also to maximize the number of such acquisitions. Achieving this goal requires an understanding of the ex post effects of lockups and also how those effects echo back into parties' behavior. My method will be to start by canvassing the existing theory before deploying my own analysis.

\section{B. The First Generation of Theory}

First generation theory starts from the premise that the interests of target managers and shareholders conflict when a takeover occurs. ${ }^{25}$ Management's jobs are often at stake, and target directors have an incentive either to reject valuable offers or to cut disloyal deals with particular bidders.

Current corporate law clearly permits management to pursue the first of these courses. Rejecting all offers from behind the safety of a poison pill, while criticized by scholars, ${ }^{26}$ has been permitted by Delaware courts. ${ }^{27}$ The second option is more difficult. Federal law prevents the sale of a company from being swiftly consummated, ${ }^{28}$ and if other bidders emerge in the delay created, management may not favor the initial bidder over its rivals. As Revlon's directors learned to their sorrow, ${ }^{29}$ once the sale of the company becomes inevitable, the eponymous "Revlon duties" are triggered and management must seek only to maximize the sale price. ${ }^{30}$

25 See, e.g., Bennett v. Propp, 187 A.2d 405, 409 (Del. 1962); CLARK, supra note 9, at 58889; Ronald J. Gilson, A Structural Approach to Corporations: The Case Against Defensive Tactics in Tender Offers, 33 STAN. L. REV. 819, 819 (1981).

26 See, e.g., Easterbrook \& Fischel, supra note 23.

27 See, e.g., Paramount Communications, Inc. v. Time Inc., 571 A.2d 1140 (Del. 1990); Unocal Corp. v. Mesa Petroleum Co., 493 A.2d 946 (Del. 1985); Moran v. Household Int'l, Inc., 500 A.2d 1346 (Del. 1985); cf. Paramount Communications Inc. v. QVC Network Inc., 637 A.2d 34, 43 n.13 (Del. 1993) In each of these decisions, the Delaware court authorized a firm's board of directors to simply decline an offer that it believed was not in the interest of the shareholders. Many states have amplified this trend by enacting anti-takeover statutes that allow management, in evaluating a tender offer, to take into account the interests of workers and the community. See, e.g., Mark G. Robilotti, Codetermination, Stakeholder Rights, and Hostile Takeovers: A Reevaluation of the Evidence from Abroad, 38 HARV. INT'L L.J. 536, 536-39 (1997) (discussing stakeholder anti-takeover statutes). Such statutes make it easier for management to reject even a bid that is clearly in the interests of target shareholders; they are commonly seen as a manifestation of corporate "capture" of state legislatures. See, e.g., Roberta Romano, The Political Economy of Takeover Statutes, 73 VA. L. REV. 111, 134-38 (1987). Delaware caselaw similarly allows management to consider "other constituencies." See Mills Acquisition Co. v. MacMillan, Inc., 559 A.2d 1261, 1282 n.29 (Del. 1988).

28 The SEC, pursuant to the Williams Act, requires a tender offer to be heid open for twenty days, in order to allow competing bids to emerge. See 17 C.F.R. $\$ 240.14$ e-1 (a) (1999).

29 Revlon, Inc. v. MacAndrews \& Forbes Holdings, Inc., 506 A.2d 173, 180 (Del. 1986).

30 Id. Revlon is often characterized as imposing a "level playing field" requirement. See, e.g., Block et al., supra note 19 , at 629. This is not entirely accurate; the Delaware courts have at least recognized the possibility that differential treatment of bidders may increase the ultimate sale price. If so, management may-indeed, should-discriminate. What is required is neutrality of judgment in comparing competing bidders (management must not be influenced by its own interests), not necessarily neutrality of treatment. See, e.g., West Point-Pepperell, Inc. v. J.P. Stevens \& Co., 542 A.2d 770, 782 (Del. Ch. 1988) ("[T]he board may tilt the playing field if, but only if, it is in the shareholders' interest to do so."). With respect to lockups, however, the praxis of Delaware courts 
In Fraidin and Hanson's evocative phrasing, management can say no, but not yes-it may reject all bidders, but cannot accept a particular bid without effectively conducting an auction. ${ }^{31}$

The first generation of theory saw lockups as a device target management could use to circumvent the unbiased auction requirement, to favor particular bidders. Because of the potential for self-dealing thus created, first generation commentators urged enhanced scrutiny. ${ }^{32}$ Most first generation scholarship operated from an ex post perspective and sought to promote efficiency. ${ }^{33}$ In this account, the danger is that management, by favoring a particular bidder in return for some benefit (such as guaranteed tenure), may prevent the highest valuing bidder from acquiring the target corporation.

The Delaware courts adopted this positive analysis, though with a slightly different normative slant. As discussed above, courts tend to employ an ex post analysis and seek to maximize shareholder revenue; this is precisely the point of Revlon duties. Lockups are threatening from this perspective because they reduce the price bidders are willing to pay for the target. All other things being equal, they reduce the price at which a sale will take place. ${ }^{34}$

Judicial approval of the first generation's ex post analysis has enshrined distrust of lockups in the caselaw. ${ }^{35}$ This is thoroughly unsurprising. If an unbiased auction is desired, devices that undermine that procedure are to be disapproved. What is slightly more surprising is the extent of the disapproval. While some lower Delaware courts have suggested that some lockups may be upheld, ${ }^{36}$ their bite has been worse than their bark. Courts strike down lockups in all cases where a "lockedout" bidder ${ }^{37}$ offers a higher bid conditioned on invalidation of the

suggests that the level playing field rule is a de facto requirement. See Fraidin \& Hanson, supra note 2, at 1743 n.13, 1765-66; infra text accompanying notes $35-39$.

31 See Fraidin \& Hanson, supra note 2, at 1743.

32 See, e.g., Bainbridge, supra note 7.

33 Some first generation scholars evaluated lockups from an ex ante perspective, also finding them undesirable. See, e.g., Schwartz, supra note 9, at 238 (arguing that lockups reduce returns to search and should be prohibited).

34 For example, if Alpha values Target at $\$ 750$ million and Beta values it at $\$ 800$ million, the sale price in an auction will ordinarily be $\$ 750$ million, the point at which Alpha will stop bidding. But if Target's management has granted a lockup of $\$ 50$ million-to either Alpha or Beta-Alpha will stop bidding at $\$ 700$ million and shareholders will receive $\$ 50$ million less from the sale. Of course, "all other things" are not usually equal; if they were, lockups would be per se disloyal and not of much academic interest.

35 See, e.g., Paramount Communications Inc. v. QVC Network Inc., 637 A.2d 34 (Del. 1993); Revlon, Inc. v. MacAndrews \& Forbes Holdings, Inc., 506 A.2d 173 (Del. 1986).

36 See, e.g., West Point-Pepperell, lnc. v. J.P. Stevens \& Co., Inc., 542 A.2d 770, 782 (Del. Ch. 1988) ("[T]he board may tilt the playing field if, but only if, it is in the shareholders' interest to do so.").

37 "Locked-in" refers to the bidder receiving the lockup and "locked-out" to rivals. 
lockup. $^{38}$

Lockups granted in situations where no bidder was willing to make a higher offer anyway are "enforceable," but obviously unimportant. More important is the fact that under this rule, even lockups that do not prevent the higher bid are voidable. If a rival bidder knows that it can get a lockup enjoined, it will always do so if the value of the lockup exceeds litigation costs. Even if it would have been willing to outbid the "locked-in" bidder, it will do better by outbidding on the condition that the lockup is invalidated. The result is that lockups can play no real role in the market for corporate control. A lockup will have value to the recipient only if it turns out that a rival bidder is (or would have been, without the lockup) willing to exceed the recipient's bid. But lockups are set aside in precisely such circumstances. Thus a lockup cannot have value to the recipient and cannot have any use in negotiations. The tool simply has been taken out of management's hands. ${ }^{39}$

\section{The Revisionists: Ayres and Fraidin \& Hanson}

The first generation analysis relies on the premise that lockups can determine who ultimately acquires a target corporation. If not, target boards cannot award victory to a favored bidder in return for job security. ${ }^{40}$ After all, if management cannot determine the winner, it cannot pick a bidder with whom to negotiate. Thus the danger of management bargaining away gains that should accrue to the shareholders (i.e., the threat to the shareholder revenue norm) seems minimal. Similarly, if lockups cannot determine who wins an auction, they obviously cannot prevent the highest valuer from acquiring the target. Thus, lockups do not threaten the efficiency norm. To reach such a benign view of lockups, the revisionists attack the first generation's essential premise through a more sophisticated ex post analysis.

38 See, e.g., QVC, 637 A.2d at 34; Revlon, 506 A.2d at 173. These cases are amply and ably summarized in Fraidin \& Hanson, supra note 2, at 1748-66. Extended recapitulation here would be redundant, and the only important conceptual point is the simple one that the de facto Delaware rule is that a lockup will be set aside if doing so will elicit a higher competing bid.

39 This is, of course, a classic ex post/ex ante mistake. Entranced by the possibility of the higher bid that is apparently precluded by the lockup, courts have failed to ask whether the locked-in bidder would have made his bid without the lockup. By adopting a legal standard under which managers cannot give that lockup to induce a bid, they will in many cases cause the auction to end earlier rather than later, and at a lower, rather than a higher price. See infra Part II.B (discussing use of lockups to increase revenue by inducing entry).

40 Lockups do have value, of course, since they are effectively cash payments to losing bidders. But a losing bidder is in no position to offer management job security, and while it could conceivably offer a cash kickback in return, this behavior reaches depths of illegality that our analysis can safely ignore. Such blatant disloyalty is always a threat, but it is handled by the duty of loyalty (and, in the takeover context, by the extensive disclosure requirements of the securities laws), not by removing all opportunities for graft. See Fraidin \& Hanson, supra note 2, at 1786-87. 
The revisionist movement starts with an insight developed by Ian Ayres. ${ }^{41}$ While a lockup, whose value is paid by the target company, reduces the amount that locked-out bidders are willing to pay for the target, it has exactly the same effect on the locked-in bidder. ${ }^{42}$ The consequence is that although a lockup may effectively reduce the cardinal amount of every bidder's valuation, it does not affect their ordinal sequence.

To see this, suppose Alpha values Target at $\$ 575$ million and Beta values Target at $\$ 600$ million. If Alpha receives a lockup worth $\$ 50$ million in return for a bid of $\$ 510$ million, Target is then worth only $\$ 550$ million to Beta, and Beta will bid only that high. Alpha still values Target at $\$ 575$ million, but this does not mean that he will outbid Beta. Because Alpha receives a profit of $\$ 50$ million by losing the auction, he will bid only up to $\$ 525$ million, the point at which he is indifferent between winning and losing. Thus, in an auction, Beta can still win with a bid of $\$ 526$ million, and he will be willing to bid that much, since he still values Target at $\$ 550$ million.

That the order of valuations is unchanged does not, however, mean that a lockup cannot change the identity of the auction winner. Ayres points out further that a greater-than-expectation lockup can foreclose rival bidders. ${ }^{43}$ Suppose that the lockup granted to Alpha in the above example is worth $\$ 100$ million rather than $\$ 50$ million. Alpha would now rather lose the auction than win at his bid of $\$ 510$ million, but Target is worth only $\$ 500$ million to Beta, and he will not beat the bid of $\$ 510$ million.

Since only greater-than-expectation lockups can affect who wins an auction, Ayres claims that only they can serve as tools of management self-interest. ${ }^{44}$ Thus, a reviewing court should add the lockup and the bid

$41 \quad$ Ayres, supra note 6.

42 "Exactly" is true in the case of a breakup fee; "proportionately" (which preserves ordinality) is true in the case of issuance of options on treasury stock. See Fraidin \& Hanson, supra note 2 , at 1771 n. 113 .

43 "Greater-than-expectation" means that the value of the lockup exceeds the profit to the bidder from winning the auction at the corresponding bid. In other words, a bidder with a greater-thanexpectation lockup would rather not win the auction. See Ayres, supra note 6, at 693 .

44 Ayres, supra note 6, at 707. It might be supposed that a "crown jewels" lockup could have different effects by destroying competing bidders' synergy gains. The error in this supposition is that it overlooks the fact that if the synergy gains from an acquisition inhere in a particular component of the target, granting a bidder a lockup on that component will probably also destroy his incentive to bid for the whole company. It will thus function simply as a greater-than-expectation lockup. The only real difference between a crown jewels lockup and a breakup fee is that a greater-than-expectation crown jewels lockup forecloses competing bidders regardless of their valuations.

Suppose that if the lockup entirely destroys synergy gains, all bidders' valuations will be reduced to the market price (below market price seems likely, but I assume market price here). Suppose the market prices Target at $\$ 100$ million, Alpha values it at $\$ 200$ million, and Beta at $\$ 250$ million. In return for a bid of $\$ 150$ million, Target grants Alpha a lockup option on the crown jewels with an exercise price of $\$ 70$ million. Even if the difference between the market price and the bidders' valuations is due entirely to the presence of the crown jewels, Beta will still be willing to bid \$169 
price and ask if this sum exceeds the bidder's possible valuation. Lockups that do are potentially foreclosing and should be enjoined; those that do not should not.

Stephen Fraidin and Jon Hanson, in the fullest flowering of revisionist theory, claim to take this approach one step further. Starting from Ayres's fundamental insight that some lockups have no foreclosing effect, they part company with him on some details of analysis and, to a greater extent, on the policy prescriptions thereby derived. First, Fraidin and Hanson note that even potentially foreclosing lockups will not always alter the outcome of an auction, because a potentially foreclosing lockup may not foreclose the highest valuing bidder. ${ }^{45}$ Second, they claim that Ayres's proposed standard is difficult to implement in practice. Identifying a potentially foreclosing lockup requires a reviewing court to ascertain the bidder's reservation price. This is no easy task. Indeed, if reservation prices were readily apparent, there would be no need for an auction mechanism to force this information into the open. ${ }^{46}$ Anticipating this difficulty, Ayres suggests that only unmistakably foreclosing lockups should be enjoined, ${ }^{47}$ but even this criterion requires courts to set a zone of reasonableness for reservation prices. Applying Ayres's standard to actual corporate practice, Fraidin and Hanson note that in the average 1980s takeover, the acquirer paid a premium of fifty percent over market price for the target's stock. ${ }^{48}$ This premium is only a lower benchmark for the acquirer's reservation price, and in consequence it seems hard to be confident that even a one hundred percent premium falls outside the zone of reasonableness. With

million. (He may prefer to negotiate with Alpha, but he is willing to bid $\$ 169$ million.) If he wins at $\$ 169$ million, he gets the company, loses the crown jewels and his synergy gains, but gets the option price of $\$ 70$ million: a value of $\$ 170$ million for a price of $\$ 169$ million. (I am assuming here that the exercise price of the option is paid to the winning bidder, rather than to target shareholders, i.e., the option is exercised after the sale.) The lockup can be made foreclosing by setting the exercise price at $\$ 49$ million. Then no matter what Beta's valuation as a result of synergy gains, he will not bid $\$ 169$ million.

This can be shown as a general result: Let $M$ be the market price, $P$ the option price, $S$ Alpha's synergy gain, and $B$ the bid price. Alpha's lockup is greater than expectation if Alpha does better by not winning the auction. This condition obtains when the difference between Alpha's synergy gain and the option price (Alpha's retum if it loses) is greater than the difference between the target's value to Alpha (the market price plus the synergy gain) and the bid: $S-P>M+S-B$. This simplifies to $P+$ $M<B$; that is, it is the condition that Alpha's bid exceeds the sum of the market valuation and the option price. Beta's retum from outbidding Alpha is $P+M-B$. When the lockup is greater than expectation (i.e., $P+M<B$ ), $P+M-B<0$ and Alpha's retum is negative, regardless of potential synergy gains.

Even a less-than-expectation lockup can be foreclosing if the optioned asset is a necessary but not a sufficient component of synergy gains. And results may differ if potential acquirers' synergy gains come from different pieces of the target. But the likely result of a foreclosing crown jewels lockup is simply negotiation between bidders, with assets moving to their highest valuing users. See Fraidin \& Hanson, supra note 2, at 1788-1803.

45 See id. at 1774-75.

46 See id. at 1775-76.

47 Ayres, supra note 6, at 706-07.

48 Fraidin \& Hanson, supra note 2, at 1778 
this wide a zone, however, the effect of Ayres's approach would be to uphold the vast majority of lockups actually granted, since lockups are typically under five percent of the purchase price. ${ }^{49}$ Ayres's approach, Fraidin and Hanson conclude, would end up "serv[ing] only as a safe harbor for disloyal boards."

Fraidin and Hanson's most ambitious claim is that even foreclosing lockups are not to be feared. To reach this conclusion they invoke "the basic lesson of the Coase theorem" "51 -if transaction costs are sufficiently low, assets will end up with the highest valuer regardless of initial entitlements. A bidder who wins an auction because of a foreclosing lockup can simply turn around and sell the company to a foreclosed higher valuer ("resale"), or even pay the higher valuer to top its bid ("presale"). In sum, bidders can contract around foreclosing lockups. While lockups may affect the outcome of auctions, they do not affect who ultimately acquires the target.

This claim has important consequences for how we think about lockups. The first-generation theory holds that lockups are offered in exchange for promises to retain management. If firms end up with the higher valuer anyway, the lockup recipient cannot help management. ${ }^{53}$ This being so, management's ability to help itself is limited largely to realizing a profit on the target shares that it holds. ${ }^{54}$ Thus, management's incentives align with maximization of target shareholder revenue. Moreover, since the highest valuer will be willing to pay the most, management's incentives also line up with the efficiency norm. In sum, lockups cannot threaten efficiency, and there is reason to suppose that they will be used to promote both efficiency and shareholder revenues. The

49 See Robert C. Schwenkel \& Judith R. Thoyer, Advanced Doing Deals: A Strategic Approach to Completing the Transaction, 1055 P.L.I./CORP. 59, 68 (1998).

50 Fraidin \& Hanson, supra note 2, at 1779. Of course, Fraidin and Hanson have no quarrel with this result. Since they believe that the specter of disloyal management employing lockups for its selfish ends is mere phantasm, they advocate de jure, not just de facto, enforcement of all lockups. Id. at 1779 n.152.

$51 \quad$ Id. at 1744 .

52 See id. at $1788-1801$.

53 At least, not by offering job security. As discussed supra note 40 , the lockup recipient conceivably could make a cash payment or, less obviously, provide altemate employment for ousted managers. But, also as discussed supra note 40 , such extremes of dishonesty make analysis very difficult. It is hardly worth ascertaining the incentive effects of various legal regimes if we assume that managers will engage in blatantly criminal acts. It makes more sense to evaluate legal rules with the assumption that actors will behave legally. Fraidin and Hanson make the further point that a well developed legal regime governing information disclosure exists to prevent such behavior. Fraidin \& Hanson, supra note 2, at 1786, 1834 nn.180-83.

54 Management typically holds "a quantity of target shares that is substantial in relation to each board member's wealth." Id. at 1804-05. A related Fraidin-Hanson argument is that even if management does receive some side compensation from a favored bidder, a higher-valuing bidder could offer both a better public price and a better side payment. $I d$. at 1785-86. This assumes, of course, that all bidders are equally inclined to graft, which may not be the case. 
revisionist account maintains that all lockups should be enforced: "like chicken soup, [they] can't hurt but may well help."

\section{The Reactionaries: Kahan \& Klausner}

Everything old eventually becomes new again, and corporate scholarship is no exception. In the most recent article on lockups, Marcel Kahan and Michael Klausner argue that lockups can affect the outcome of bidding contests and decry their effects on the disciplinary function of the market for corporate control, echoing the classic tenets of first-generation scholarship. $^{56}$

Kahan and Klausner maintain that lockups can affect auctions because they can determine who bids. ${ }^{57}$ Bidding is costly, and potential acquirers will enter auctions only if their expected returns exceed bidding costs. A lockup granted to the first bidder will not generally deter highervaluing bidders from entering the auction. ${ }^{58}$ However, a lockup granted to a second bidder may induce it to enter an auction it otherwise would not. If the lockup is in the amount of bidding costs, entry is riskless. ${ }^{59}$ Lockups cannot prevent higher valuers from acquiring targets, but they may be used to induce other bidders to enter the auction and, if they are higher valuers, to acquire the target. ${ }^{60}$

From an ex post perspective, all of this is unobjectionable. Lockups cannot reduce allocative efficiency and may promote it. They also increase shareholder revenue. The important contribution of Kahan and Klausner is to return the focus to the ex ante effects. Their distinction between firstand second-bidder lockups is especially apt in this regard. Whatever else

55 Id. at 1745.

56 Kahan \& Klausner, supra note 7 . The threat of a hostile takeover is widely considered one of the strongest promoters of managerial efficiency. Because inefficient companies become targets, and inefficient managers will be displaced, managers have an incentive to perform. See, e.g., Edgar v. Mite Corp., 457 U.S. 624, 643 (1982); Lucian A. Bebchuk, The Case for Facilitating Competing Tender Offers, 95 HARV. L. REV. 1028, 1047 (1982); Easterbrook \& Fischel, supra note 9, at 2; Roberta Romano, $A$ Guide to Takeovers: Theory, Evidence, and Regulation, 9 YALE J. ON REG. 119,130 (1992). The efficacy of the disciplinary effect may be significantly overstated, however, because the legal playing field currently tilts substantially towards managers resisting a hostile offer. See supra notes $27-31$ and accompanying text.

57 Kahan \& Klausner, supra note 7, at 1546-51.

58 If the lockup is greater than the first bidder's expected return, it may prevent a higher valuer from entering. Ayres comments that greater-than-expectation lockups are "extreme," Ayres, supra note 6 , at 684 , and Kahan and Klausner ignore them as irrelevant to the argument. Kahan \& Klausner, supra note 7 , at $1545 \mathrm{n} .20$.

59 Entry is riskless because the bidder will receive the lockup $L$ if he loses the auction, and will thus bid no higher than his valuation minus the lockup $(v-L)$. He is guaranteed a retum of the value of the lockup, at a minimum. To be precise, risk is eliminated only if the bidder's valuation exceeds his entering bid by more than his bidding costs $(v-b>c)$. Since, by hypothesis, $L=c$, this condition amounts to the requirement that $v-b>L$, or $v>b+L$. This is simply the requirement that the lockup is less-than-expectation, which seems reasonable.

60 See Kahan \& Klausner, supra note 7, at 1548-49. 
second-bidder lockups may do, they transfer profits from the initial bidder to shareholders. ${ }^{61}$ They thus reduce returns to search and will dampen takeover activity. ${ }^{62}$ Kahan and Klausner argue that second-bidder lockups should be strictly scrutinized. ${ }^{63}$ First-bidder lockups, in contrast, should be analyzed under the business judgment rule. ${ }^{64}$

\section{The Theory Synthesized}

\section{A. Reactionary Failings}

Kahan and Klausner are right to focus on the ex ante effects of lockups. Their conclusion, however, rests in large part on faulty reasoning because they discount the effects of current takeover law, fail to engage fully the revisionist analysis, and neglect the well-developed body of auction theory applied to corporate acquisitions.

The primary value that Kahan and Klausner ascribe to the market for corporate control is that it disciplines managers by threatening them with hostile takeovers if they perform inefficiently. The ability of takeovers to play this role, however, has been seriously, if not fatally, compromised by Delaware's recognition of the "just say no" defense. ${ }^{65}$ Recalcitrant management may eventually be unseated; a would-be acquirer need only wait for a shareholders' meeting, win a proxy contest, and have its own

61 The initial bidder may simply lose its search and investigation costs if a lockup induces a higher valuer to bid. Even if the initial bidder ultimately acquires the target, it will do so at a higher price. See id. at $1552-54$.

62 The argument that reducing returns to search is undesirable obviously depends on the premise that the current level of search is not excessive. This has been contested, with one of the prominent points being that the first bidder can ensure some profit by buying $5 \%$ of the target's stock at or near the market price before announcing its bid. See Lucian A. Bebchuk, The Case for Facilitating Competing Tender Offers: A Last (?) Reply, 2 J.L. ECON. \& ORG. 253, 255 (1986). This possibility, clearly, does not change between a lockup and a no-lockup world; it has no effect on our comparison of the two unless it suggests that there is excessive search. But the excessive search thesis appears to be disfavored. In fact, it seems more plausible to suppose that efficiency is best served by allowing acquirers to capture all of the surplus from an acquisition. See, e.g., Elazar Berkovitch et al., Tender Offer Auctions, Resistance Strategies, and Social Welfare, 5 J.L. ECON. \& ORG. 395, 399 (1989); Cramton \& Schwartz, supra note 23, at 33 n.14. Setting acquirer gain equal to social gain will induce investment in search until the marginal cost exceeds the marginal surplus produced. If we think that the surplus created by takeovers is real social value, this is the regime we would want. Clearly it is not the one we have, and second-bidder lockups move us farther away.

63 Kahan \& Klausner, supra note 7, at 1564-65. Kahan and Klausner advocate the same level of scrutiny for "anticipatory" lockups, meaning those granted in anticipation of a hostile bid. Id.

64 See id.

65 See, e.g., Moran v. Household Int'l, Inc., 500 A.2d 1346 (Del. 1985); Paramount Communications, Inc. v. Time Inc., 571 A.2d 1140 (Del. 1990); cf. Paramount Communications Inc. v. QVC Network Inc., 637 A.2d 34, 43 n.13 (Del. 1993). As mentioned above, the recent legislative tendency has been to augment, rather than undermine, management's ability to reject hostile bids. Recent anti-takeover statutes permit management to reject even offers that are indisputably in the shareholders' interests by invoking the interests of workers or local communities. See supra note 27. 
directors redeem the poison pill. Yet, this process can drag on for years if the board is classified ${ }^{66}$ and it offers ample time for inefficient directors to remedy their conduct. ${ }^{67}$ Of course, hostile takeovers do occur, and they do not all take place over a period of years. The flaw in Kahan and Klausner's argument is not that managers can always fight off a hostile bid, but rather that they would be foolish to attempt to do so by means of a lockup. ${ }^{68}$

Lockups are not a good defensive tool. The first reason is that, as the revisionists claim (and Kahan and Klausner agree), a lockup will not prevent a higher valuer from acquiring the target. Management relying on a lockup must gamble on the possibility that its chosen "white knight" values the company more highly. More importantly, by doing so, it acquiesces to the sale of the company and loses its far more effective ability to say no. ${ }^{69}$

A second reason, which Fraidin and Hanson discuss at length, ${ }^{70}$ is that if the takeover is motivated by management inefficiency, as most hostile takeovers are, ${ }^{71}$ the target initially will have the same value to each potential acquirer, because each will have the same plan (dump the shirkers) to increase its value. ${ }^{72}$ Deals that entrench management will reduce the target's value to the locked-in bidder; they can no longer fire the inefficient managers. In consequence, a locked-out hostile bidder, even if uncertain about the target's value, can confidently outbid management's

66 A "classified" board is composed of classes of directors, each of which comes up for election in a different year. See 1 ARTHUR Fleischer \& AlEXANDER R. SUSSMAN, TAKEOVER DEFENSE $\S 6.05$ (a), at 24 (5th ed. 1995). Thus a nine-member board might be composed of three classes of three, and control could not be obtained until two elections had taken place. "Cumulative voting" can make it still more difficult to wrest control from incumbents. Under cumulative voting, each share is allotted one vote per seat to be filled but may cast more than one vote for a particular candidate. For $n$ vacancies, the $n$ candidates receiving the highest vote totals are elected. For example, when one class comes up for election, with three seats to be filled and 10,000 shares outstanding, management holding 2501 shares would get 7503 votes. If management casts all 7503 votes for one candidate, a would-be acquirer with 7499 shares (and 22,497 votes) could not put three candidates above the 7503 mark and management would be able to elect one candidate. Thus, even if management holds barely more than one quarter of the 10,000 voting shares, cumulative voting would allow it to elect one member of each three-director class. This would force an acquirer to wait three elections to gain a majority. In general, with cumulative voting, a shareholder may elect $m$ candidates (from $n$ seats) by holding $x+1$ shares (out of $y$ total) where $x=(y * m) /(n+1)$.

67 By shaping up their act and bringing the market value of the company up to what it would be if managed efficiently, directors can eliminate its attractiveness as a target. From an ex post perspective, the disciplinary effect might seem intact, but the would-be acquirer will realize small gains at best. (It might, for example, be able to make a profit on the $5 \%$ of target shares the Williams Act permits it to buy, see 15 U.S.C. $\S 78(\mathrm{~m})(\mathrm{d})$, before the de facto auction starts.) The ex ante consequence will be that returns to search for unwilling targets are low.

68 See Fraidin \& Hanson, supra note 2, at 1827 n.344.

69 This is precisely what happened in Revlon, Inc. v. MacAndrews \& Forbes Holdings, Inc., 506 A.2d 173 (Del. 1986). A poison pill defense was succeeding when the Revlon board contacted a "white knight" and thereby triggered its eponymous duty to auction. See id. at 177.

70 See Fraidin \& Hanson, supra note 2, at 1809-10.

71 See Cramton \& Schwarz, supra note 23, at 47.

72 See id. 
chosen suitor.

Lockups are thus also poor tools for serving management's disloyal interests. Attempts to bargain for continued tenure are self-defeating. The concerns that drive Kahan and Klausner's ex ante anxieties are not as substantial as they might seem. Managers will use lockups neither to fend off hostile takeovers nor to cut illicit side deals. More likely, they will attempt simply to increase the value of their stock holdings by extracting higher bids. The ex post analysis of the revisionists stands.

But I come not to praise Fraidin and Hanson. In the end, I will claim that Kahan and Klausner have the more persuasive prescription. Understanding why requires a more sophisticated analysis of the effects of lockups than the reactionaries deploy, and this in turn requires the use of auction theory.

\section{B. Auction Theory Applied}

For analytical clarity, auctions are commonly divided into two types: "common value" and "independent private value."" A common value auction occurs when the asset in question has an identical worth to each bidder. The classic example of a common value auction is the auction of oil leases. Because each bidder intends to sell the oil and has roughly the same ability to extract and market it, the lease is worth the same to each bidder. In an independent private value auction, the asset's value differs for different bidders. Art, whose consumption value to bidders depends on taste, is an independent private value asset. A further distinction exists within the common value category: bidders may be able to discover the value of the asset (common value with certainty) or they may not (common value with uncertainty).

Takeover auctions may be of either type. If the acquisition is motivated by inefficiencies of target management, and each potential acquirer intends to take the same remedial steps, the value produced will be the same no matter which bidder wins the auction. However, if bidders have different uses for the target and different synergy gains from the acquisition, the auction will feature independent private values.

Real-world auctions tend to be mixed rather than a pure example of either type: oil leases will have different values to bidders depending on production costs, and the possibility of resale will inject a common value element into art auctions. ${ }^{74}$ Nevertheless, an understanding of the effects of lockups is advanced by considering their use in the common and independent private value paradigms.

73 See id. at 28-29. Auction theory also contemplates different auction mechanisms, but the Williams Act essentially mandates an ascending-bid auction, so this is the form I will discuss.

74 See id. at 29 n. 47 . 


\section{Common Value Auctions}

As noted above, common value auctions are further divided into two classes, depending on whether certainty about value is possible. The following analysis shows the operation of both of these types of auctions without lockups, and how the availability of lockups changes the outcomes.

Assume that there is a positive cost to the investigation required to ascertain the common value and to prepare an initial bid (the "entry cost"). This is true of corporate acquisitions (though I do not mean to suggest that many acquisitions do feature common values with certainty) since potential acquirers need to investigate the target, line up financing, and retain lawyers to draft the offer. Assume further that making a second or subsequent bid is costless; this is of course not true, but the assumption simplifies analysis and is roughly accurate, because the initial investment dwarfs the costs of merely changing numbers in a document.

In a common value situation with certainty, there will be no real auction. Only the first bidder will bid. ${ }^{75}$ After a first offer is made, any other potential entrant will know that if an auction takes place, bidders will continue raising their bids until they reach the common value. The winner's profit will be negligible; given that entry costs are positive, entering the auction has a negative expected value and no other bidder will enter. The result of an auction regime would thus be that the initial bidder wins the "auction" at his first bid-presumably a price marginally above the market price. All the surplus (the excess of value over market price) thus goes to the first bidder.

Use of lockups to subsidize bidding can produce a nearly opposite distribution of the surplus. By granting a lockup to a potential second bidder, target management can ensure this bidder a minimum return of the lockup value. ${ }^{76}$ If the lockup exceeds entry costs, the second bidder will have a positive expected return and will enter the auction. The bidding will then proceed to the common value minus the lockup (given the assumption that rebids are costless) and the target shareholders will obtain all of the surplus, less the value of the lockup. ${ }^{77}$ Of course, the ex ante effect of this prospect is that the first bidder, knowing that management will subsidize a second bidder, will not enter without a lockup. Management thus will be forced to grant lockups to both bidders and the sale price will be the common value minus two lockups. In effect, target shareholders gain the surplus but bear all transaction costs, since the value of the lockups must

\footnotetext{
75 See id. at 33.

76 See supra text accompanying note 59.

77 If the target knows the value, it can extract all the surplus merely by threatening to conduct an auction. See Cramton \& Schwartz, supra note 23 , at 33.
} 
be equal to both bidders' entry costs. ${ }^{78}$

Common value auctions with uncertainty are the more interesting, and the more typical, case. Assume that each bidder has equally good information, and that all bidders know this. That is, each bidder trusts every other bidder's estimation of the target's value as much as it trusts its own. (Bidders do not, of course, know each other's estimations at the beginning of the auction.) Assume further that the estimations are normally distributed around the correct value. Finally, assume that bidders will not bid above their own estimations. Again, these assumptions make the analysis more tractable by creating an idealized auction. To the extent that real-world conditions depart from the model, its predictions will suffer, but it is useful because it establishes the ideal from which departures are made. The conclusions I draw about the effects of lockups do not demand perfect accuracy.

Because bidders are uncertain as to the target's value, they will update their estimates as rivals drop out of the auction and reveal their own estimates. ${ }^{79}$ In this type of auction, seller's revenue increases with the number of bidders. This is so because sale will take place at the secondhighest valuer's adjusted estimation; that is the point at which only the highest valuer will remain in the auction. More bidders supply more information. Thus in auctions with more bidders, the second-highest valuer's adjusted estimation will be closer to the actual value. If bidders' estimates are evenly distributed around the actual value, the actual value is the limiting value for the sale price. ${ }^{80}$

The number of bidders is a function of entry costs and expected return. In deciding whether to enter, each new potential bidder compares the costs of entry (investigation and bidding) to its expected return. Thus, lower entry costs produce more bidders. Higher expected return also produces more bidders, but expected return is itself a function of the number of bidders. As the number of bidders increases, each bidder is less likely to win; thus, the expected return decreases for each new bidder.

78 See id. Since only two bidders are required to drive the price up to the common value minus the lockups, management has no incentive to induce other bidders to enter. Indeed, it has an incentive not to, since each lockup granted reduces the value of the target to bidders and thus the ultimate sale price, as discussed earlier. See supra text accompanying note 42 . Consequently, in common value auctions with certainty, management will subsidize only two bidders.

79 See Cramton \& Schwartz, supra note 23, at 35. If Alpha refuses to beat a bid of $x$ million dollars, other bidders learn that its estimation of Target's value is no greater than $x$ million. They will use this information to update their own estimates; specifically, where $n$ bidders remained before Alpha dropped out, each remaining bidder will reduce its estimate, $e_{i}$, by $\left(e_{i}-x\right) / n$. That is, given the assumption that all bidders have equally good information and are equally likely to have estimated Target's value correctly, the rational response to the disclosure of the lowest estimation (rather than a randomly disclosed estimation) is to revise by a factor that takes into account the number of bidders remaining. See R. Preston McAfee \& John McMillan, Auctions and Bidding, 25 J. EcON. LIT. 699, $722-73$ (1987).

80 See id. at $721-22$. 
Equilibrium occurs when entry costs equal expected return. Past this point, no new bidders will enter. (This verbal description may be somewhat opaque; the following section employs a more explicit model.)

The conclusion that follows immediately from the above discussion is that low entry costs increase target revenue. But they do so only because they increase the number of bidders, and any factor that induces more bidders to enter will also increase revenue. In particular, lockups allow management to simulate low entry costs by guaranteeing locked-in bidders some minimum return. The analysis below will show that this is undesirable because it reduces returns to search and increases aggregate transaction costs. Less obviously, first-bidder lockups allow managers to increase revenue by deterring entry. This tactic is desirable from the ex ante perspective because it also increases returns to search.

\section{a. Using Lockups To Increase the Number of Bidders}

I will employ a slightly simplified version of the model used by Cramton and Schwartz. ${ }^{81}$ As noted above, I assume that each bidder is equally likely to be correct, that estimations are normally distributed around the true value, and that all bidders are aware of these conditions. The model will show that use of lockups, by simulating low entry costs, can increase seller revenue ex post, but that the ex ante effects of the tactic, as applied to corporate acquisitions, undercut the ex post effects, with the general consequence a reduction in shareholder revenue. In assessing the ex ante effects, I make the further assumption that there are search costs in identifying likely targets. I assume that these costs are born entirely by the first bidder, since the making of a bid signals to other bidders that the target is worth purchasing.

Each bidder decides whether or not to enter the auction by comparing entry costs $c$ to expected return. Expected return is the winner's profit $p$ multiplied by the chance of winning. The chance of winning is $1 / n$, where $n$ is the number of bidders. $P$ is the difference between the sale price and the actual value. It is a function of $n$ and the standard deviation between estimations. $^{82}$

Entry will occur until the cost of entry equals the expected return: $c=p / n$. At this equilibrium point, the last bidder has a zero expected return from the auction process as a whole. ${ }^{83}$ Importantly, all the other

81 Cramton \& Schwartz, supra note 23 , at 34.

82 Greater differences between estimations will produce a greater difference between the sale price and the actual value. Thus winner's profit increases with a greater standard deviation. More bidders will supply more information to the bidder with the second-highest estimation, and bring its estimation closer to the actual value. Thus, the winner's profit decreases with a greater number of bidders.

83 This bidder expends entry costs $c$ and expects to gain $p / n$, which by hypothesis equals $c$. 
bidders are in the same situation. They have expended $c$ and expect to recover only that amount from the auction. Management can induce another bidder to enter by granting a lockup. Lockups increase expected return, and so management can raise the locked-in bidder's expected return above $c$. In this case, where a locked-in bidder enters past the equilibrium point, the expected return of all other bidders will fall below $c .^{84}$

This use of lockups has almost no harmful effects from an ex post perspective. ${ }^{85}$ Management has fulfilled its fiduciary duty to maximize shareholder revenue, ${ }^{86}$ and the corporation has been acquired by a highervaluing user. From an ex ante perspective, however, it is disastrous. All locked-out bidders have negative returns from the auction process. They will also have incurred investigation costs, and the first bidder will also have incurred search costs. Anticipating management's use of lockups to induce entry, ${ }^{87}$ these bidders will be unlikely to search for the target and will not enter the auction without receiving lockups themselves. With reduced search, fewer acquisitions will occur, and the efficiency gain created by transferring companies to higher valuers will be reduced. Furthermore, since target shareholders are less likely to receive takeover premiums, shareholder revenue is also likely to suffer.

\section{b. Using Lockups To Reduce the Number of Bidders}

Given the threat of lockup-induced entry detailed above, no bidder will enter a common value auction without some form of compensation if second-bidder lockups are permitted. One obvious tactic would be for management to grant a first-bidder lockup. This has been suggested by a number of commentators as a way of increasing both shareholder revenue and returns to search, ${ }^{88}$ which would make the tactic desirable both for courts and for scholars. Revisionists thus endorse first-bidder lockups as

84 Each bidder's expected return is reduced by each new entrant. The chance of winning obviously decreases as the number of bidders $n$ increases; less obviously, the winner's profit also decreases since the sale price goes up. Since equilibrium represents the point at which the expected retum is equal to bidding costs, entry past equilibrium will drive the expected retum below bidding costs and, consequently, drive the net return below zero.

85 "Almost" because management's use of the lockup to induce entry is undesirable from an efficiency perspective. By inducing another bid, it has increased aggregate transaction costs.

86 In addition to inducing entry, the lockup will also reduce the value bidders place on the target. This effect reduces the sale price by the value of the lockup, and indeed, if the lockup is equal to bidding costs, the increased revenue from the higher number of bidders will be canceled out. The revenue effect will predominate if the lockup is less than bidding costs. It is possible to bring expected retum above entry costs $c$ with such a lockup, since participation in the auction has a positive value $(p / n)$.

87 Management cannot credibly promise not to use lockups, because it cannot bargain with potential acquirers before they sink their search costs.

88 See, e.g., Cramton \& Schwartz, supra note 23, at 36-37; Fraidin \& Hanson, supra note 2, at 1826-28; Kahan \& Klausner, supra note 7, at 1563-64. 
part of their general panegyric; reactionaries exempt such lockups from their philippic.

On this point, the revisionists are wrong for two reasons. First, if no bidder will make a bid without a lockup, management's ability to choose the initial bidder creates an adverse selection problem. ${ }^{89}$ Management can shop among potential bidders to find one that overvalues the target. Under the full-enforcement regime that the revisionists advocate, target managers will often be able to sell firms for more than they are worth. ${ }^{90}$ Returns to search will obviously be reduced. Second, the conclusion to draw from the fact that first-bidder lockups can be useful to offset the danger of secondbidder lockups is not that all lockups should be permitted, but that secondbidder lockups should be prohibited. The danger of adverse selection is reduced if bidders will be willing to enter auctions without lockups. They will be willing to do so if there is no threat of management inducing entry past the equilibrium point by granting lockups. ${ }^{91}$ Prohibiting second-bidder lockups achieves this goal.

The reactionaries have the advantage of assuming that second-bidder lockups will be prohibited; thus, they at least start from the appropriate baseline. However, from this point they cannot advance the ball. They encounter a serious problem when they attempt to explain why loyal management would grant a first-bidder lockup, if not to compensate for the danger that they might grant second-bidder lockups. As Fraidin and Hanson point out, "[n]o loyal target would grant and no bidder could credibly demand a lockup for investments already made in identifying and evaluating the target ....,"92

If the lockup is not compensation for sunk costs (that would be irrational), nor inducement to enter the auction (that would be unnecessary), what could its use be? After all, a lockup lowers all bidders' reservation prices; if it does not induce entry, it reduces shareholder revenue in an equilibrium auction. Kahan and Klausner offer no clear answer to this question. They note correctly that first-bidder lockups do not reduce returns to search, but do not explain why such lockups are not per se disloyal..$^{93}$ Auction theory does, by showing that managers can increase revenue by granting first-bidder lockups in order to reduce entry

89 Cf. Cramton \& Schwartz, supra note 23 , at 35 (noting adverse selection problem).

90 This is a hypertrophied version of the "winner's curse" that attends common value auctions generally. The conventional "winner's curse" appears as a consequence of the fact that the highest valuer is likely to overvalue the target. It can be avoided if bidders adjust their estimations to take into account the information revealed by other bidders who stop bidding. But if management can obtain information about bidders' estimations without the bidders also gaining the information, no such avoidance is possible.

91 Simply paying the entry costs of a later bidder has the same effect and must likewise be forbidden.

92 Fraidin \& Hanson, supra note 2, at 1814

93 See Kahan \& Klausner, supra note 7, at 1563-64. 
in return for a higher bid. ${ }^{94}$

Denote the initial bidder's estimation of the target's value by $e$. Both this bidder and the target can calculate the bidder's expected return $p / n$ from an auction that reaches equilibrium based on knowledge of bidding costs and estimation distribution. This expected return will be less than the winner's profit $p$ in such an auction, because there will be more than one bidder. The initial bidder and the target thus can both do better than they would in an equilibrium auction by negotiating a sale price $s$ which is greater than the estimation minus the auction winner's profit, but less than the estimation minus the expected return from the auction for each bidder, that is:

$$
e-p<s<e-p / n
$$

A sale price in this range is higher than the anticipated sale price in an equilibrium auction $(e-p)$, but the buyer still does better than he expects to do by entering an auction, because $s<e-p / n$. More explicitly, the bidder and the target both know that in an equilibrium auction, the bidder's expected return is $p / n$. They both also know that the sale price will be the target's value $v$ less the winner's profit $p$. (They do not, of course, know the value; I discuss this point below.) The difference between $p$ and $p / n$ is the surplus created by avoiding an auction; it represents the transaction costs saved. ${ }^{95}$ The bidder and the target can bargain over this surplus and arrive at a sale price $s$ where $v-p<s<v-p / n$.

There are two problems with this procedure. First, it is a negotiated sale of a company, precisely what the Williams Act's auction requirement prevents. ${ }^{96}$ The solution to this problem is to grant the bidder a lockup in the amount of $v-s$. This "expectation" lockup ensures the initial bidder that even if the Williams Act delay produces an auction and the target goes to another bidder, he will receive his bargained-for profit. The second problem is that neither party knows the value. The solution to this is to use the bidder's estimation. (Hence the use of $e$ in place of $v$ in the earlier formulation.) In the long run, estimations will prove accurate; from the perspective of repeat players, variations will net out. For evaluating the efficiency of the legal rule, that is the perspective we should adopt.

There is one further difficulty that threatens to prevent the variations from netting out. It is a variant of the "winner's curse" discussed above.

94 In equilibrium common value auctions, the target's revenue is equal to its expected value less aggregate transaction costs. See Cramton \& Schwartz, supra note 23, at 35 . But merely deterring entry, though it does reduce aggregate transaction costs, will not ipso facto increase revenue. A higher bid must be obtained.

95 See supra note 94

96 See supra note 4.

97 See supra note 90. 
If the bidder seriously undervalues the target, it is unlikely to reap the full benefits of its mistake; another bidder may well appear and snap up the target despite the lockup. But if the bidder seriously overvalues the target, the bidder may well pay more than it is worth, even though the bidder is paying less than its estimation. The consequence of this is simply that bidders will bargain slightly harder than we might otherwise expect. ${ }^{98}$

Of course, negotiation is always fraught with the potential for strategic behavior, and there are complicated factors at play here. A bidder may have incentives to understate its valuation in hopes of getting a bargain. Other bidders may be hesitant to top even a "lowball" bid because the danger of the "winner's curse" in this situation is real. ${ }^{99}$ Management's leverage lies in its ability to offer a less-than-expectation lockup if it feels the bidder is lowballing, or to opt for the auction if negotiations break down. What can be said generally about this use of first-bidder lockups is that it creates a surplus to be divided between searchers and shareholders. It is hard to believe that it will not make them both better off. From an ex ante perspective, first-bidder lockups in common value auctions are desirable as a way to increase returns to search and to promote efficiency by reducing the transaction costs of auctions. They also increase revenue, but this effect is incidental from the efficiency perspective. Second bidder lockups, by contrast, reduce returns to search and should be prohibited. ${ }^{100}$

\section{Independent Private Value Auctions}

Independent private value auctions occur where the target has different values to different bidders. ${ }^{101}$ In this auction environment, sale will occur at the second-highest valuer's valuation, since that is where the

98 The adverse selection that was so troubling above is not a concem here, because if negotiations break down, the bidder still has a positive expected retum from entering the auction. Thus, he will make his bid and start the process. Management lacks the club provided by second-bidder lockups and cannot extract information from bidders while preventing them from revealing it.

99 The "winner's curse" is a result of the fact that in a common value auction, the bidder with the highest estimation is likely to overvalue the target. In an ascending-bid auction, the effect is greatly reduced. The information provided by lower estimators as they stop bidding allows higher estimators to revise their estimates. If a negotiated lockup forecloses lower estimators from bidding, the information they would provide goes undisclosed, and higher estimators are more likely to bid too much.

100 Where the first bidder has received an expectation lockup as a result of the negotiation process described above, second-bidder lockups will reduce returns to search only slightly. The first bidder is indifferent to winning or losing the auction, and the only way in which the presence of other bidders makes him worse off is by depriving him of a windfall profit where he has significantly undervalued the target. This effect might be small enough that it would make sense to permit secondbidder lockups where the first bidder has received a lockup, if these second-bidder lockups served some important policy goal. Because maximizing target shareholder revenues is not such a goal, there is no reason not to prohibit second-bidder lockups.

101 In the takeover context, this will usually result from synergy gains. Bidders will have different uses for the target's assets and, consequently, different values for the target. 
bidding will end. Assuming that bidders' valuations are randomly distributed, an increase in the number of bidders will tend to increase the second-highest valuation, though the effect weakens as the number of bidders grows. Consequently, shareholder revenue is increased by increasing the number of bidders. ${ }^{102}$ Second-bidder lockups, which can induce entry, can therefore increase shareholder revenue. ${ }^{103}$

First-bidder lockups, on the other hand, reduce shareholder revenue in two ways. First, lockups reduce all bidders' reservation prices. They thus reduce the second-highest valuer's valuation, which is the ultimate sale price in an independent private value auction. Second, a first-bidder lockup may deter entry. A bidder who values the target at less than the sum of the lockup and the first bidder's bid will not enter the auction. If the first bidder is the highest valuer, the second highest valuer may not enter the auction, and the sale price will be reduced. ${ }^{104}$ Target shareholder revenue is thus maximized by permitting second-bidder but not first-bidder lockups. ${ }^{105}$

Maximizing target shareholder revenue has adverse consequences for efficiency. In the common value auction, we saw, target shareholder revenue and returns to search may both be increased by reducing transaction costs. In the independent private value environment, no such possibility exists. Returns to search may be increased only by reducing revenue; here the tradeoff between returns to search and target shareholder revenue is a zero-sum game. Thus, increasing returns to search requires the reverse treatment: enforcing first-bidder but not second-bidder lockups. First-bidder lockups, by guaranteeing some return, increase the first bidder's expected profit and may also reduce the sale price. Second-bidder

102 See McAfee \& McMillan, supra note 79, at 710-11.

103 They may also be used to override "ratcheting bids," as in Revlon. In that case, Pantry Pride offered $\$ 56.25$ per share and promised to beat any competing bids by five cents a share. See Fraidin \& Hanson, supra note 2, at 1754-55. The lockup subsequently enjoined was granted to Forstmann Little \& Co., the rival bidder, in return for a bid of $\$ 57.25$. If the ratcheting promise were believed, Forstmann Little would be irrational to make this bid without a lockup, and the auction would have ended at \$56.25. See Revlon, Inc. v. MacAndrews \& Forbes Holdings, Inc., 506 A.2d 173, 178 (Del. 1986). In contrast to the Delaware court's conclusion, the Revlon lockup was in the best interests of shareholders. See Fraidin \& Hanson, supra note 2, at 1754-55.

104 See Fraidin \& Hanson, supra note 2, at 1806-09.

105 Fraidin and Hanson suggest that collusive first-bidder lockups may increase target shareholder revenue. $I d$. at 1824-26. Their analysis is somewhat implausible, because it requires two assumptions: first, that the target can identify a higher valuer, and second, that a potential acquirer can be induced to bid above his valuation in the expectation that the higher valuer will exceed his bid. It is more likely, in such cases, that the higher valuer will simply negotiate with the locked-in bidder.

Assume that in such a negotiation, the target will be sold for a price midway between the two valuations. Let $v /$ be the lower valuation, $v 2$ the higher, $b$ the bid, and $L$ the lockup. The higher valuer's choice is between $l / 2(v 2-v l)$ (negotiation) and $v 2-(b+L)$ (topping the bid). The higher valuer will top the bid where $I / 2(v 2-v l)<v 2-(b+L)$, which becomes $v 2+v />2(b+L)$. That is, he will top the bid if the sum of the two valuations is more than double the sum of the bid and the lockup. 
lockups that induce entry reduce the probability that the first bidder will win. They also may increase the price he will have to pay, and they clearly reduce the value of the target to him; the cumulative effect reduces returns to search.

\section{Policy Prescriptions}

Asking courts to distinguish between common and independent private value acquisitions is certainly impractical and likely impossible. ${ }^{106}$ However, the analysis above shows that both types of auctions can be regulated consistently. ${ }^{107}$ We have seen that enforcing lockups increases shareholder revenue ex post in both common value ${ }^{108}$ and independent private value ${ }^{109}$ auctions. From the perspective of maximizing target shareholder revenue ex post, all lockups should be enforced. Courts have thus implemented precisely the wrong rule to reach their stated goal. From the ex ante perspective, the issue is more complicated. Lockups increase the price at which acquisitions take place, but precisely because they increase price, they reduce frequency. Sellers get bigger paydays, but there will be fewer sales, since buyers will be less inclined to seek out targets. Although it is hard to gauge which effect predominates, ex ante revenue maximization might well require prohibition of lockups. ${ }^{110}$

Of course, I have embraced an ex ante efficiency perspective, and from that angle things look somewhat different. If the goal is to maximize efficiency ex ante, first-bidder lockups should be enforced and secondbidder lockups should be prohibited. ${ }^{111}$ In common value auctions with certainty, this treatment allows the first bidder to capture almost all of the surplus, since no other bidder will enter. ${ }^{12}$ In common value auctions

106 See Cramton \& Schwartz, supra note 23, at 46.

107 From an ex ante efficiency perspective, the best way to "regulate" auctions might well be to prohibit them. See id. at 50-51. This would require repeal of the Williams Act and proscription of some defensive tactics. This Article limits its analysis to different possible treatments of lockups, since neither of the above changes seems likely.

108 See discussion supra Part II.B.I.

109 See discussion supra Part II.B.2. Of course, it is true that first-bidder lockups in independent private value auctions tend to reduce revenue. However, target managers will generally try to maximize revenue. See Fraidin \& Hanson, supra note 2, at 1786-87. The danger of imprudent firstbidder lockups is small, so permitting first-bidder lockups-which is necessary to increase revenue in common value auctions--does not threaten revenue in independent private value auctions.

110 . The courts seem to have made two mistakes that largely cancel each other out. They have erred first by taking an ex post perspective, trying to maximize sale price in individual transactions without considering the general effect of their rule, which is to decrease shareholder revenue. Second, they have failed to see that lockups, in the hands of competent management, do increase shareholder revenue ex post.

111 Kahan and Klausner, focusing on hostile acquisitions, argue that first-bidder lockups granted in anticipation of a hostile bid should be severely scrutinized. Kahan \& Klausner, supra note 7 , at 1559. Because lockups are an inferior defensive tactic, this concern is chimerical.

112 See discussion supra Part II.B.1. 
without certainty, it allows management to reduce the transaction costs expended in an auction and thereby increase the surplus available to divide between buyers and sellers. ${ }^{113}$ In both types of common value auctions, enforcing first-bidder but not second-bidder lockups both reduces transaction costs and increases returns to search, which encourages valuecreating transactions.

In independent private value auctions, by contrast, the choice between efficiency and shareholder revenue is more stark. First-bidder lockups are beneficial from the ex ante efficiency perspective. They increase the first bidder's returns to search and help the buyer partially circumvent the auction regime imposed by the Williams Act. However, it is not clear why management would grant first-bidder lockups, because they do not increase shareholder revenue ex post. ${ }^{114}$ Yet, concerns about management rationality should not lead to greater scrutiny. Courts cannot distinguish between common and independent value private value auctions; indeed, the two types of auctions may intermingle. Because first-bidder lockups do increase shareholder revenue in common value auctions, management's offer of a first-bidder lockup may be no more than a sign that they believe the auction is a common value auction.

Thus far, the prescriptions of this Article largely follow the reactionary account of Kahan and Klausner. Courts should only enforce first-bidder lockups. However, the theory underlying the suggested treatment of lockups differs. The danger of lockups is not that disloyal management will prevent value-creating takeovers. Managers have more effective devices with which to do so. Nor will lockups allow disloyal management to siphon off the gains from an acquisition. Lockups are poorly suited for this role, because such deals reduce the likelihood that the locked-in bidder will acquire the target. The problem with lockups, from the ex ante perspective, is that loyal management will use them to increase shareholder revenues. This will decrease acquirer profits and reduce returns to search. Search is important not so much as a disciplinary device-its ability to serve that function is undermined by the defensive tactics target management can employ and is not affected by lockups-but simply because takeovers create value.

This theoretical divergence may not seem important at first glance. However, it will produce different prescriptive results if background conditions are altered. Understanding what lockups can and cannot do is critical when the context changes.

113 See discussion supra Part II.B.1.b.

114 See discussion supra Part II,B.2. Management is, of course, bound by its duty of loyalty to promote shareholder revenue ex post; the challenge is to craft legal rules which will lead management's attempts to efficient results. 


\section{Lockups in Bankruptcy}

While mergers and acquisitions has been a hot field of late, bankruptcy has not. Business bankruptcy filings, after climbing for two years, dropped to 44,367 in $1998 .{ }^{115}$ But a glance at the data shows that the number of filings cycles, and more than anything else, the current lull is a chance to consider how to deal with the next wave. In particular, it is important not to suppose that lockups in bankruptcy simply present the same issues as they do in the market for corporate control. Mergers increase in good times, and bankruptcy filings in bad, but the contexts are not two sides of the same coin; they need to be distinguished in terms of the appropriate treatment of lockups. Ascertaining the differences, and arriving at appropriate policy recommendations, is the task of this Part.

Bankruptcy is a fertile field for the application of lockup theory, although the use of lockups in bankruptcy transactions appears to be a relatively recent phenomenon. ${ }^{116}$ First, a sale of assets in bankruptcy, even if not conducted as an auction, has auction-like qualities, because a sale outside the ordinary course of business requires judicial approval. ${ }^{17}$ The delay thus imposed, coupled with the probability that a bankruptcy judge will rule in favor of a competing hi.her bidder, creates an effective auction. Second, companies in Chapter 11 may seek out mergers as part of a plan of reorganization and are sometimes the targets of hostile takeover attempts. Finally, a number of scholars have suggested that Chapter 11 should be replaced by an auction of insolvent companies. In this case, the proper use of lockups would again be important.

Given these facts, it is no surprise that courts have recently found themselves forced to evaluate the use of lockups in bankruptcy. What is slightly more surprising is that the bankruptcy law on the subject is largely simply an adoption of nonbankruptcy law. ${ }^{118}$ If the nonbankruptcy treatment of lockups is misguided, as both revisionist and reactionary scholars argue, then its mistakes must be considered; if bankruptcy differs in relevant ways from the nonbankruptcy context, these differences must also be weighed. I suggested above that the judicial treatment of lockups may, ironically, be largely correct from an efficiency perspective. A normative mistake (privileging shareholder revenues over efficiency) and a

\footnotetext{
115 See U.S. Bankruptcy Filings 1980-1998 (visited Dec. 2, 1999) $<$ http://www.abiworld.org/stats/newstatsfront.html>.

116 The earliest reported case appears to be In re 995 Fifth Ave. Assocs., 96 B.R. 24 (Bankr. S.D.N.Y. 1989).

117 See 11 U.S.C. \$363(b) (1994).

118 Courts used to reason by analogy to cases that held that the business judgment rule protects lockups; currently, they seem more inclined to import the Revlon duty-to-auction level of scrutiny. See supra note 111. Neither analysis, however, is informed by a sensitivity to the unique features of bankruptcy.
} 
positive mistake (thinking that lockups reduce revenues) combine to produce the correct result. But though two wrongs may make a right, three do not. Add to the above confusion the positive mistake of assimilating bankruptcy to nonbankruptcy, and the wrong treatment arises again.

\section{A. Current Theory}

The current theory on lockups in bankruptcy mirrors the first generation's distrust of lockups in the market for corporate control. The two most influential scholarly pieces ${ }^{119}$ both call for increased judicial scrutiny and parade first-generation horribles. ${ }^{120}$ Neither of these writings reflects the recent nonbankruptcy developments, and necessarily so given that they predate both the revisionists and the reactionaries. More surprising is the fact that neither displays a sophisticated understanding of lockups, bankruptcy, or their interaction. And perhaps most surprising, the academic consensus appears to be winning the hearts and minds of the judiciary. While the early cases dealing with lockups in bankruptcy displayed inconsistency in the level of scrutiny applied, ${ }^{121}$ more recent cases take a much harder line. Agreeing with, and often citing, the academic denunciations of lockups, the recent cases argue that lockups should be evaluated by courts and should be permitted only if in the best interests of the estate. ${ }^{122}$

The normative conclusion here is fairly unobjectionable. The analysis proposed is similar to the one Delaware courts claim to use: determine whether the lockup makes the seller better off. However, like the Delaware test, this standard is unworkable because it is impossible to implement.

119 See Lackey, supra note 14; Markell, supra note 14. Hebbeln, supra note 14, reaches the correct conclusion, but his note's cloudy reasoning has limited its impact.

120 Markell's general complaint about lockups is that they reduce sale prices. See Markell, supra note 14, at 364-69. While Markell does not explain why managers would employ devices that have this result, Lackey invokes the specter of management opportunism, which he claims is more serious in bankruptcy. See Lackey, supra note 14, at 736-37.

121 These cases divide on the question of whether lockups are protected by the business judgment rule. For an affirmative answer, see In re Integrated Resources, Inc., 135 B.R. 746 (Bankr. S.D.N.Y. 1992). For a negative variation, see In re Hupp Industries, 140 B.R. 191 (Bankr. N.D. Ohio 1992), which calls for higher scrutiny. In re Crowthers McCall Pattern, Inc, 114 B.R. 877 (Bankr. S.D.N.Y. 1990), approves a breakup fee without discussion. 995 Fifth Ave. Assocs., 96 B.R. at 24, takes a middle (and arguably incoherent) ground: Lockups are protected by the business judgment rule unless they are too large and chill bidding. Presumably, application of the business judgment rule would prevent the court from making this inquiry, so the announced rule seems difficult to apply. Even the Integrated Resources court, however, remarked that "the subject court is charged with the duty of reviewing the agreement to determine that it is reasonable in relation to the bidder's efforts and the magnitude and significance of the transaction, and will enhance rather than detract from the bidding process." Integrated Resources, 135 B. R. at 753.

122 See In re Tiara Motorcoach Corp., 212 B.R. 133, 137 (Bankr. N.D. Ind. 1997); In re S.N.A. Nut Co., 186 B.R. 98, 101-02 (Bankr. N.D. Ill. 1995) (citing Lackey, supra note 14; Markell, supra note 14); In re America W. Airlines, 166 B.R. 908, 912 (Bankr. D. Ariz. 1994) (citing Markell, supra note 14). 
context, most of the academic commentary correctly rejects the judicial notion that maximizing target shareholder revenue ex post is a worthy goal. ${ }^{131}$ In bankruptcy, maximizing return may be significantly more important. The expected return in bankruptcy will factor into a creditor's decision to make a loan, and it will be reflected in the terms of the loan. Bankruptcy rules that maximize return to creditors have the effect of making credit available more cheaply. Insofar as one wants to support economic growth and activity, one might want a rule that maximizes returns to creditors. ${ }^{132}$

\section{Lockups Are Not Needed To Attract Bidders}

Markell and Lackey both characterize bankruptcy as a "must-sell" situation. ${ }^{133}$ Because management actively seeks out buyers, they argue, they do not need lockups to attract bidders. This claim seems to misconceive the role of lockups; as Fraidin and Hanson persuasively argue, "no loyal target would grant and no bidder could credibly demand a lockup for investments already made in and identifying and evaluating the target." ${ }^{34}$ Lockups are not used to attract bidders.

Again, however, this argument illuminates an important difference between bankruptcy and nonbankruptcy. The major concern about lockups from the ex ante efficiency perspective is that they transfer gains from bidders to shareholders and reduce returns to search. This reduction in search incentives is significant when finding a profitable target is an expensive proposition. However, the concern has less force in the bankruptcy context, where search costs are greatly reduced. A firm seeking to sell assets may advertise this by publication; a firm seeking a merger may seek out and contact potential acquirers. In fact, the above approaches feature prominently in the caselaw dealing with lockups in bankruptcy. ${ }^{135}$ Additionally, while the would-be acquirer of a solvent company can buy

131 See, e.g., Cramton \& Schwartz, supra note 23, at 28; see also supra text accompanying notes 19-22. Ex ante maximization of the wealth of all (rather than just target) shareholders is a more reasonable policy goal, but it seems unlikely that maximizing the sale price in acquisitions contributes to this goal.

132 Shareholders of course play a similar role in providing capital. But it is all shareholders, rather than target shareholders alone, who do so. Maximizing target shareholder revenue ex post has an uncertain effect on shareholder wealth in general. In contrast, the creditors of a bankrupt corporation do represent the appropriate class. Moreover, maximizing creditor revenue ex post does not produce ex ante effects that threaten creditor revenue, while the reduction of returns to search produced by ex post maximization of target shareholder revenue does threaten to dampen the very activity that produces takeover premiums.

133 Lackey, supra note 14, at 736; Markell, supra note 14, at 360-69.

134 Fraidin \& Hanson, supra note 2, at 1814.

135 See, e.g., In re Crowthers McCall Pattern, Inc., 114 B.R. 877, 878 (Bankr. S.D.N.Y. 1990) (offering memoranda sent to potential acquirers); In re Alpha Industries, 84 B.R. 703, 704 (Bankr. D. Mont. 1988) (involving the sale of assets advertised by publication). 
no more than $5 \%$ of target stock before announcing its intentions, ${ }^{136}$ an acquirer in bankruptcy may be able to do better by buying up claims while facing no analogous restriction. ${ }^{137}$ Thus, increasing returns to search, a significant concern in the market for corporate control, is of lesser importance in bankruptcy.

\section{Management Opportunism Is More Threatening}

Lackey claims that management opportunism presents more of a danger in bankruptcy. ${ }^{138}$ It is certainly true, as he contends, that management is more likely to be disloyal. In the takeover context, managers may have some incentive to behave disloyally. If they want to keep their jobs, they may reject acceptable offers. Once it becomes clear that the company will change hands, however, management's incentives mostly align with those of shareholders. Since the highest valuer will acquire the company, and since inefficient management likely will be fired by the highest valuer, management's efforts focus mostly on getting a profit on its stock by maximizing sale price. ${ }^{139}$

The bankruptcy context is quite different. Maximizing revenue, if the company is insolvent, is likely to help neither management nor shareholders generally, because the equity stake is underwater. Management in Chapter 11 may thus have incentives to invest inefficiently; ${ }^{140}$ with respect to sales of assets or of the company, it has little incentive to maximize return. ${ }^{141}$ To the extent that management can use lockups to siphon off gain from auctions, it will do so by taking the gain directly, not by profiting from an increased sale price.

However, the claim that management opportunism is more

136 See 15 U.S.C. \& 78m(d) (1994).

137 While the Williams Act probably does not apply to the buying of secured claims in bankruptcy, see Chaim Fortgang \& Thomas Myers, Trading Claims and Taking Control of Corporations in Chapter II, 12 CARDOZO L. REV. 1 (1990), there is some authority for the proposition that it does apply to the purchase of unsecured claims. See SEC v. Texas Int'l Co., $498 \mathrm{~F}$. Supp. 1231, 1240 (N.D. Ill. 1980). Additionally, it may be that buying up claims is sufficiently similar to proposing a reorganization plan to trigger the disclosure requirements of 11 U.S.C. § 1123(a) (1994). See In re Allegheny Int'l, Inc., 100 B.R. 241, 243 (Bankr. W.D. Pa. 1988)

138 Lackey, supra note 14, at 736-38.

139 See Fraidin \& Hanson, supra note 2, at 1785-1804.

140 Management, as equity holders, is indifferent both to loss and to gain that does not restore solvency. Thus, it may either take projects that have an expected negative returm but offer a slim chance of a very large payoff (overinvestment), or it may ignore projects with an expected positive return but no chance of a large payoff (underinvestment). See Schwartz, supra note 21, at 1824.

141 This problem can be mitigated to some extent by tying management's compensation to creditor returns, a technique used with apparent success in the Johns-Manville reorganization. See Lynn M. LoPucki \& William C. Whitford, Corporate Governance in the Bankruptcy Reorganization of Large, Publicly Held Companies, 114 U. PA. L. REv. 669, 689 n.76 (1993) (discussing Johns-Manville reorganization). 
threatening in bankruptcy requires more than greater incentives to disloyalty; it requires some ability for disloyal self-promotion. The interests of the management of an insolvent company diverge from those of creditors. But lockups in bankruptcy do not seem to provide them with an effective tool for pursuing their own gain. Continued tenure, the compensation most often cited by opponents of lockups, is unavailable in a bankruptcy sale of assets. Even where this is a possibility, i.e. merger within Chapter 11 or an auction alternative, the Bankruptcy Code requires the disclosure of identities of officers- and directors-to-be, and a reviewing court must find such appointments or continuances "consistent with the interests of creditors and equity security holders and public policy."142 Furthermore, as in the nonbankruptcy context, an acquirer that intends to retain inefficient management is unlikely to be the highest valuer and, therefore, unlikely to acquire the target.

Conflict between creditors and the debtor's management usually reflects the fact that creditors prefer quick sales to acquire cash, while the debtor prefers attempts to reorganize. ${ }^{143}$ Lockups, which only come into play during a sale, do not give the debtor any effective leverage in this dispute. ${ }^{144}$ Indeed, management's ability to help itself may be limited to prolonging its tenure by dragging out the reorganization processsomething Chapter 11 allows it to do quite effectively. ${ }^{145}$ However, while this is a serious concern, it does not seem relevant to an analysis of lockups. In bankruptcy, lockups are, if anything, a slightly less effective tool of management self promotion. ${ }^{146}$

142 See 11 U.S.C. § 1129(a)(5)(A)(ii) (1994).

143 See Schwartz, supra note 21, at 1807, 1821.

144 It would also be possible for management to use a foreclosing lockup to sell assets to confederates at a discount. This is similar to the cash payment in return for a lockup discussed supra note 40 . It seems a reasonable response that if management is willing to go to these lengths to exploit creditors, lockups are probably not necessary for their nefarious schemes. Additionally, the sale of assets requires judicial approval, and a below-value sale is not likely to succeed where there is evidence of self-dealing. Finally, awareness of this possibility does not affect the prescription that lockups should be protected by the business judgment rule. A self-dealing transaction falls outside the boundaries of the business judgment rule, and bankruptcy courts are capable of scrutinizing deals between related parties, such as management-led leveraged buyouts. See, e.g., In re Bidermann Indus. U.S.A., Inc., 203 B.R. 547, 552 (Bankr. S.D.N.Y. 1997) (refusing to apply the business judgment rule to a breakup fee in a related-party LBO). Striking down a lockup in such a case does not rely on any inherent suspicion of lockups.

145 For example, the Bankruptcy Code grants the debtor-in-possession exclusive rights to propose a plan for the first 120 days, see 11 U.S.C. $§ 1121$ (b) (1994), and this period is often extended. Lopucki and Whitford's empirical study, however, concludes that whether management will ally itself with shareholders or with creditors is unpredictable. See LoPucki \& Whitford, supra note 141, at 744. If this is the case, lockups are even less to be feared.

146 See Markell, supra note 14. Markell makes no mention at all of why management might want to grant a supracompensatory lockup; he seems almost to be suggesting that lockups should be strictly scrutinized because management is incompetent, rather than corrupt. America West and S.N.A. $N u t$, which both approve Markell's reasoning, similarly suggest that breakup fees in bankruptcy sales of assets are a waste of estate funds without offering any reason why the debtor would be disposed to such waste. See In re S.N.A. Nut Co., 186 B.R. 98, 103 (Bankr. N.D. Ill. 1995); In re America W. 


\section{Bankruptcy Purchases Are a Bargain}

Markell and Lackey share one more argument about relevant differences between bankruptcy and nonbankruptcy. They claim that purchasers of assets or companies enjoy substantial benefits because the seller is in bankruptcy. This follows as a result either of the fact that a company in Chapter 11 can reject unprofitable executory contracts and assume profitable ones, ${ }^{147}$ or that purchasers of assets in bankruptcy are assured of getting good title. ${ }^{148}$ Both these assertions are true, but while they suggest that bankruptcy sales should take place at slightly higher prices than they would outside of bankruptcy, they are otherwise irrelevant. The value of the assets being auctioned, and rules that may increase that value, have nothing to do with the propriety of lockups.

\section{Summary}

The case against lockups in bankruptcy, as it is currently stated, rests on some very questionable arguments. However, these arguments reveal important differences between bankruptcy and the market for solvent companies. First, maximizing returns to creditors is an important goal. Second, search is much less costly. Third, management will in some cases be less able to promote its own interests by using lockups. Given that this Article's earlier analysis suggested that second-bidder lockups work precisely to increase revenue at the expense of bidders, it seems likely that bankruptcy presents a best case scenario for lockup proponents. The following sections take a closer look at lockups in a few different bankruptcy situations.

\section{Lockups in Bankruptcy Sales of Assets}

The points developed above apply quite directly to bankruptcy sales of assets; these are perhaps the easiest case for the lockup advocate. ${ }^{149}$ Under the restrictions imposed by the Bankruptcy Code, a sale of assets will resemble a common value with uncertainty auction. As Part II.B demonstrated, first-bidder lockups in such auctions play the desired role of maximizing seller revenue; they also increase returns to search, although I have suggested that this is not a serious concern. And since management

\footnotetext{
Airlines, 166 B.R. 908, 912 (Bankr. D. Ariz. 1994). S.N.A. Nut, in fact, commented that merger and acquisition lockup cases "are really not similar to the bankruptcy cases since most involve allegations of breach of fiduciary duty by the directors." S.N.A. Nut, 186 B.R. at 101 n.5.

147 See 11 U.S.C. $\$ 365$ (1994); Lackey, supra note 14, at 736.

148 See Markell, supra note 14, at 377.

149 It is thus somewhat surprising that the most fervent denunciations of lockups seem to be found in sale of assets cases. See, e.g., S.N.A. Nut, 186 B.R. at 105.
} 
Markell suggests that "the debtor should grant, and the bankruptcy court should approve, a breakup fee only if there is a showing that the fee induces an increased bid by the amount of the fee, and if the amount of the fee correlates with the fee that other bidders would have received." ${ }^{23}$ This formulation is a nice example of the difficulties courts face in trying to differentiate between lockups that increase revenue and those that reduce it. Suppose that negotiation produces an initial bid/lockup package. How can it be shown that the lockup increased the bid by a certain amount? The standard seems to do nothing more than create a safe harbor for disloyalty. Management can protect a lockup of almost any size by negotiating an artificially low "first offer" that is then "raised" in return for a lockup. ${ }^{124}$

Because distinguishing between good and bad lockups is so hard, the Delaware ex ante test collapses into a de facto relevance rule. Effective lockups may be enjoined. ${ }^{125}$ The bankruptcy approach similarly appears to be in the process of collapsing into a strong presumption against lockups: "[A]bsent compelling circumstances which clearly indicate that payment of the fee would be in the best interests of the estate, breakup fees should not be awarded in bankruptcy auction sales.",126

The central contention of revisionist scholarship is that distinguishing between good and bad lockups is not difficult at all, because there is no such thing as a bad lockup. I have suggested that while this conclusion is correct ex post, it may need rethinking with respect to the ex ante effects of a rule permitting lockups. Use of second-bidder lockups seems likely to reduce returns to search, with negative effects on both target shareholder revenues and efficiency. The question is what the import of these facts is in the bankruptcy context.

\section{B. The Case Against Lockups}

Markell and Lackey raise a number of arguments designed to show that lockups in bankruptcy should be disfavored. An examination of their major contentions helps to uncover both the aspects of lockup theory that need to be updated and the relevant differences between bankruptcy and nonbankruptcy.

123 Markell, supra note 14 , at 366.

124 See Fraidin \& Hanson, supra note 2, at 1751

125 See supra text accompanying notes 345-38.

126 S.N.A. Nut, 186 B.R. at 105. 


\section{Creditors Bear Costs Directly}

Both Markell and Lackey note that any estate funds spent on lockups reduce the funds otherwise available to pay creditors. ${ }^{127}$ This is a somewhat surprising point on which to focus, because the same is obviously true with respect to target shareholders in the nonbankruptcy context. The idea that there is a difference may stem from the fact that in a bankruptcy sale of assets, the seller corporation survives and pays a breakup fee to a losing bidder. The direct effect of the breakup fee is thus not to reduce the value of the assets to other bidders, but to reduce the value of the bids to the seller. ${ }^{128}$

Mathematically, the point is the following: If an insolvent corporation enters into an agreement to sell assets at a price of $\$ 150$ million and grants a breakup fee of $\$ 15$ million to Alpha, Beta, who values the assets at $\$ 160$ million, will not be prevented from bidding. Beta will be willing to pay $\$ 160$ million for the assets. The bid of $\$ 160$ million, however, will be worth only $\$ 145$ million to the selling corporation since if they accept it, they have to pay the breakup fee of $\$ 15$ million to Alpha.

It is, of course, mistaken to suppose that this represents a real difference in the effect of breakup fees. Whether the breakup fee is paid from buyer to seller and then repaid from seller to losing bidder or whether it is paid out of the value of the acquired asset (and hence directly from buyer to losing bidder), the money moves from the winning bidder to the loser. ${ }^{129}$ The only difference is the number of steps taken to get there. The above example comes out the same if the breakup fee of $\$ 15$ million is taken to be paid out of the value of the asset, reducing its value to $\$ 145$ million.

Thus, the argument as phrased does not relate to any real difference between bankruptcy and nonbankruptcy. Creditors and target shareholders both bear the costs of lockups directly; the Bankruptcy Code's focus on maximizing returns to creditors matches the judicial structuring of takeover law to maximize returns to target shareholders. That lockups "come out of creditors' pockets"130 is by itself neither a difference between bankruptcy and nonbankruptcy, nor a reason to scrutinize lockups more closely.

There is, however, an important point lurking here. In the takeover

127 Lackey, supra note 14, at 721; Markell, supra note 14, at 374-76.

128 See In re Financial News Network, Inc., No. 91B-1089! (FGC), 1991 WL 127524 (Bankr. S.D.N.Y. May 10,1991).

129 This does not mean, of course, that lockups necessarily reduce returns to winning bidders; only foreclosing lockups have this effect.

130 Lackey, supra note 14 , at 738 
tenure is not an issue in a sale of assets, lockups are at best a clumsy tool of management disloyalty. ${ }^{150}$

The judicial analysis of these transactions is insensitive to the theory developing around lockups, and it is remarkable how completely insensitivity translates into mistake. Courts assume that lockups can pose a significant threat to target shareholder revenues ex post; theory suggests this is unlikely. Moreover, the threat posed is almost uniformly characterized as the danger of "chilling" bidding. ${ }^{151}$ Yet theory shows that in a common value auction with uncertainty, chilling bidding is desirable. Revenue maximization and efficiency are best served by granting a firstbidder lockup in return for a higher negotiated bid. ${ }^{152}$ Management may also be able to obtain an even higher offer by subsequently granting a second-bidder lockup; because of the importance of creditor revenue, these should not be prohibited. ${ }^{153}$ A proper understanding of the effects of lockups in bankruptcy sales of assets suggests that they should always receive the protection of the business judgment rule.

\section{Lockups and Takeovers Within Chapter II}

\section{Friendly Acquisitions}

Friendly mergers do occur in the context of Chapter 11 reorganizations. ${ }^{154}$ Such a merger may offer creditors considerably more than they could receive otherwise, and may be the only way for an insolvent firm to survive as a going concern. Where a merger is contemplated in Chapter 11, lockups play the same role that they do in the ordinary merger and acquisition context. The analysis developed in Part II suggests that first-bidder lockups should certainly be accorded the protection of the business judgment rule. In common value auctions with uncertainty, such lockups increase both creditor revenue and returns to search. In independent private value auctions, they tend to reduce creditor revenue. However, management is unlikely to be able to serve any disloyal

150 Fraidin and Hanson make a strong argument against the idea that management can use lockups to bargain for continued tenure. Fraidin \& Hanson, supra note 2, at 1788-1804. And given that this will often not be at issue in a sale of assets (unless divisions of the company are being sold and will be preserved), management would be forced to improbable extremes of disloyalty to siphon any gain.

151 See In re Hupp Indus., 140 B.R. 191, 194 (Bankr. N.D. Ohio 1992); see also, e.g., S.N.A. Nut. 186 B.R. at 103; America West, 166 B.R. at 913; see also In re 995 Fifth Ave. Assocs., 96 B.R. 24, 28 (Bankr. S.D.N.Y. 1989) (supporting the same notion without utilizing the "chilling" language).

152 See Cramton \& Schwartz, supra note 23, at 34-35; discussion supra Part II.B.1.

153 See discussion supra Part II.B.1.

154 See, e.g., In re Crowthers McCall Pattern, Inc., 114 B.R. 877 (Bankr. S.D.N.Y. 1990) The Crowthers court did approve the breakup fee, without comment. Id. at 890 . 
goals by granting a first-bidder lockup, and most takeovers within Chapter 11 will be common value transactions. ${ }^{155}$ Since courts are unlikely to be able to identify the type of auction taking place, they will do better to evaluate all first-bidder lockups under the business judgment rule. ${ }^{156}$

Less obviously, and in contrast to the ordinary mergers and acquisitions context, second-bidder lockups in friendly acquisitions should also be evaluated under the business judgment rule. Maximizing creditor revenue is an important goal, and since insolvent companies seek out potential acquirers, the reduced returns to search are not a serious drawback.

\section{Hostile Acquisitions}

If managers of companies in Chapter 11 are more likely to be inefficient than those of solvent companies, one might expect to see more interest in takeovers of insolvent companies. One would also expect greater resistance, because inefficient management knows that it is likely to be displaced in an acquisition. Chapter 11 provides management with defensive resources that significantly exceed those of solvent companies.

Management of an insolvent company may enjoin a shareholders' meeting, preventing insurgents from replacing the board. ${ }^{157}$ Managers enjoy exclusive rights to propose a plan of reorganization for the first 120 days, and often gain more time from reviewing courts. ${ }^{158}$ Buying creditors' claims against the estate, which carry power to vote on proposed plans, is not as simple as buying voting stock because courts may disallow votes that they deem were cast in bad faith. ${ }^{159}$

The hazards of attempting an acquisition in Chapter 11 are welldemonstrated in the case of Allegheny International. ${ }^{160}$ Japonica Partners tried to gain control of Allegheny by buying claims from its creditors. Control over a sufficient amount of claims would have allowed Japonica to block management's proposed plan of reorganization and compel acceptance of its own plan. During voting on the debtor's proposed plan, Japonica bought bank claims and senior unsecured debt in sufficient

155 Cramton and Schwartz claim that most takeovers are motivated by management inefficiency and hence are common value transactions. Cramton \& Schwartz, supra note 23, at 47. Assuming, as seems probable, that companies in bankruptcy are more than usually likely to be poorly managed, the percentage of common value acquisitions in that context will be even higher.

156 A basic principle of corporate law, but one that merits repeating, is that the business judgment rule does not apply to self-dealing transactions. See, e.g., In re Bidermann Indus. U.S.A., lnc., 203 B.R. 547, 551 (Bankr. S.D.N.Y. 1997). Thus a management LBO would receive strict scrutiny. See id.

157 See Fortgang \& Myers, supra note 137, at 63.

158 See id.

159 See 11 U.S.C. \& $1126(\mathrm{e})$ (1994).

160 In re Allegheny Int'l, Inc., 118 B.R. 282 (Bankr. W.D. Pa. 1990). 
quantities to obtain veto power. The reviewing court disallowed these votes as being cast in bad faith under 11 U.S.C. $\$ 1126(\mathrm{e}) .^{161}$

Japonica also made a tender offer for subordinated debentures and debentures of Allegheny's subsidiary. The offer price was less than the amount paid to debenture holders under the Japonica plan, and the purchases were held to violate the Bankruptcy Code's prohibition ${ }^{162}$ against discriminatory treatment of creditors in the same class. ${ }^{163}$ Finally, after some members of the unsecured creditors' committee voted against the Japonica plan, Japonica purchased their claims at a premium. This was deemed "a naked attempt to purchase votes."164

The difficulties facing a hostile acquirer in Chapter 11 appear almost insuperable. Certainly, as Allegheny International shows, management has defensive resources far more effective than lockups. Thus, while management recalcitrance is a problem in bankruptcy, lockups are not a part of it. A desire to promote hostile acquisitions should not lead to a prohibition of bankruptcy lockups. Moreover, lockups do have beneficial effects. As the analysis in Part II.B shows, lockups increase seller revenue ex post. In the ordinary takeover context, the diminished returns to search both threaten efficiency goals and make the ex ante revenue effect unclear. But since, in bankruptcy, seller revenue is an important goal and search is less costly, a rule that promotes seller revenue ex post is desirable. Once again, all lockups should be evaluated under the business judgment rule.

\section{Policy Prescriptions}

There are a number of reasons why companies in Chapter 11 may be inviting targets for acquisition. An insolvent company is probably relatively more likely to be mismanaged; thus the potential exists for efficiency gains. And, as is generally the case, acquisitions may create synergy value. The distinctive feature of bankruptcy is that target management is more likely to seek out potential acquirers. ${ }^{165}$ As a result, there is less need to worry about returns to search. As already noted, the maximization of creditor revenue is a more important goal than the maximization of target shareholder revenue. ${ }^{166}$ Maximization of revenue requires that all lockups be protected by the business judgment rule,

161 See id. at $287-90$.

162 See 11 U.S.C. $\$ 1123(a)(4)(1994)$.

163 See Allegheny Int'l, 118 B.R. at 294-96.

164 Id. at 297.

165 See In re Financial News Network, Inc., No. 91B-10891 (FGC), 1991 WL 127524 (Bankr. S.D.N.Y. May 10, 1991) (offering memoranda sent to potential acquirers); In re Crowthers McCall Pattern, Inc., 114 B.R. 877 (Bankr. S.D.N.Y. 1990) (same).

166 It is also indisputably the focus of the Bankruptcy Code. 
whether in common value or independent private value auctions. ${ }^{167}$

\section{E. Lockups and a Chapter 11 Auction Alternative}

One way of facilitating hostile takeovers in bankruptcy would be to eliminate Chapter 11 altogether. Legal theory is replete with criticisms of Chapter 11. Many scholars have argued that it impedes the flow of assets to their highest-valuing users. ${ }^{168}$ Moreover, while the firm is in Chapter 11 , there are good reasons to suppose that it is not pursuing the course of action optimal from the perspective of either creditor revenue or efficiency. ${ }^{169}$ Professors Bradley and Rosenzweig argue that both stockholders and bondholders do worse under the current Chapter 11 than they did under its predecessor. The effect of Chapter 11 is to transfer wealth from debt and equity to management. ${ }^{170}$

Given these criticisms, there has been a surge of interest in developing alternatives to Chapter 11 . Most scholars propose replacing it with some sort of market-driven mechanism, often an auction of the company. ${ }^{171}$ If an auction alternative is adopted, there is the further question of how the auction should be conducted.

Differences between bankruptcy and nonbankruptcy suggest that the primary goal for a Chapter 11 auction alternative should be maximizing return to creditors, i.e., obtaining the highest possible sale price. ${ }^{172}$ Auction theory reveals that in a common value auction with uncertainty, negotiating a first-bidder lockup and then offering lockups in return for higher bids maximizes revenue. In an independent private value auction, revenue is maximized by granting second-bidder lockups to induce entry.

The difficulty with these prescriptions is that the seller may not know which auction type obtains. Moreover, the environment may be mixed. While auctions may be divided into common value and independent

167 See discussion supra Part II.B.2.

168 See THOMAS H. JACKSON, THE LOGIC AND LIMITS OF BANKRUPTCY LAW (1986); Douglas G. Baird, The Uneasy Case for Corporate Reorganizations, 15 J. LEGAL STUD. 127 (1986); Lucian A. Bebchuk, A New Approach to Corporate Reorganizations, 101 HARV. L. REV. 775 (1988); Mark J. Roe, Bankruptcy and Debt: A New Model for Corporate Reorganization, 83 ColuM. L. REV. 527 (1983); Erica Ryland, Note, Bracing for the "Failure Boom": Should a Revlon Auction Duty Arise in Chapter II?, 90 COLUM. L. REV. 2255 (1990).

169 See Joseph E. Stiglitz, Some Aspects of the Pure Theory of Corporate Finance: Bankruptcies and Take-Overs, 3 BELL J: ECON.-MGMT. SCI. 458 (1972) (noting management's incentives to overinvest); see also discussion of overinvestment and underinvestment supra note 140.

170 See Michael Bradley \& Michael Rosenzweig, The Untenable Case for Chapter. 11, 101 YALE L.J. 1043, 1047-50 (1992). But see Elizabeth Warren, The Untenable Case for the Repeal of Chapter 11, 102 YALE L.J. 437 (1992) (offering a rebuttal to Bradley and Rosenzweig). The debate over the value of Chapter 11 is live; this Article does not attempt to resolve it. It suggests only that if an auction alternative is adopted, lockups could play a valuable role. note 168 .

171 See Baird, supra note 168; Bebchuk, supra note 168; Roe, supra note 168; Ryland, supra

172 See discussion supra Part III.B.5. 
private value for the purposes of theory, most will feature both sorts of bidders. ${ }^{173}$ Auctions of insolvent companies are likely to present the possibility of gains from more efficient management (a common value aspect), but there may also be synergy gains that vary across bidders. What follows is a technique that maximizes revenue in mixed auctions.

Assume that potential bidders $b_{1} \ldots b_{n}$ have been assembled. Each has an estimate of the target's value to it and can incur investigation costs $k$ to obtain better information. The board, or a trustee appointed to conduct the auction, should, before entertaining bids for the target, conduct an auction for a ratio of bid to lockup. Because a higher bid will produce a larger lockup, the bidder with the highest estimated valuation should win the pre-auction. ${ }^{174}$

This pre-auction should be fairly inexpensive, because bidders avoid all investigation costs and at least some bidding costs, in that they do not need to arrange financing and presumably have less need of lawyers. Once the winner $b_{x}$ of the pre-auction is determined, it incurs investigation costs $k$ and makes a bid for the target, incurring bidding costs $c$ and receiving a lockup in the agreed-upon ratio.

The seller obviously hopes that this offer is the highest bid $b_{x}$ would be willing to make at that ratio, i.e., that the bid and the lockup combined equal $b_{x}$ 's informed valuation. The seller also hopes that $b_{x}$ has the highest informed valuation. If this is the case, the sale price will substantially exceed that obtained in an auction. ${ }^{175}$ Because $b_{x}$ 's informed valuation is private, and because no other bidders have incurred investigation costs, the seller cannot be sure of these facts. The next step thus is to invite the other bidders to decide whether the bid is a lowball, or whether they have higher valuations, by offering a lockup in the amount of investigation and bidding costs $(k+c)$ in return for a higher bid. If other bidders think that the target is worth more to them than $b_{x}$ 's bid-lockup sum, they can incur investigation costs $k$ to find out. In order to give $b_{x}$ the greatest possible incentive to make a high first bid, the seller should also refuse to entertain subsequent offers from $b_{x}{ }^{176}$

173 See supra note 74 and accompanying text.

174 To see this, suppose Alpha believes the target is worth $\$ 145$ million, and Beta estimates it at $\$ 195$ million. If bidding and investigation costs are $\$ 5$ million, Alpha can offer a ratio of $28: 1$ to get an expectation lockup of $\$ 5$ million in return for a bid of $\$ 140$ million. Beta can offer a ratio of 38:1 for the same size lockup-a bid of $\$ 190$ million for an expectation lockup of $\$ 5$ million. (The ratio that produces an expectation lockup will be the highest a bidder is willing to go.) The result of a preauction in this case would be that Beta wins at slightly over the $28: 1$ ratio.

175 Retum to the example in the preceding footnote, where Beta has won the pre-auction. Suppose subsequent investigation confirms Beta's initial estimate. (Uncertainty about this does not affect the general result.) If Beta bids based on this valuation, the $28: 1$ ratio will produce a bid of $\$ 188.28$ million and a lockup of $\$ 6.72$ million. This price is substantially higher than the sale price in an auction between Alpha and Beta, since such an auction would terminate at Alpha's reservation price of $\$ 145$ million, assuming that subsequent investigation also confirmed Alpha's estimate.

176 It might seem that there is no reason to bar higher rebids from the initial bidder, as these 
With these rules, $b_{x}$ has only a limited incentive to lowball because this bid will very likely be topped, in which case $b_{x}$ receives only the lockup. If $b_{x}$ shades down its bid, the lockup is likewise decreased. ${ }^{177}$ Bidding so that bid and lockup sum to valuation produces the largest lockup and hence the largest guaranteed return.

This use of lockups seems likely to produce an auction that harmonizes efficiency and revenue maximization goals. By reducing transaction costs, it should maximize revenue in a common value auction with uncertainty; by allowing higher valuers to reveal themselves, it should maximize revenue in an independent private value auction and direct assets to their highest valuing user.

Conclusion

The revisionist account of lockups is convincing in its ex post analysis. From that perspective, lockups pose no threat to target shareholder interests. They are likely to increase target shareholder revenue; in fact, they succeed too well in doing so. Because management has little incentive to worry about appropriate levels of search, and indeed has a legal obligation to maximize shareholder revenue ex post, ${ }^{178}$ the use of lockups is likely to benefit target shareholders at the expense of bidders, thereby reducing returns to search. ${ }^{179}$ From an ex ante efficiency

may simply reflect upward revision of an initial good faith estimate in light of competing bids. The analysis makes sense ex post. However, since rebidding is relatively cheap compared to the initial investigation, the ex ante consequence of this approach would be to encourage lowball first bids. That would lead, in turn, to a greater number of auctions (as other bidders will be willing to top the lowball bid) and greater wasted transaction costs. Moreover, a bidder can credibly claim to have revised its estimate upwards in light of other bidders' behavior only when the asset has a common value that cannot be known with certainty. It is precisely in this context that revenue is increased by deterring entry and avoiding the wasteful auction. See discussion supra Part II.B.1.b.

177 There may be room for bidder speculation. Suppose that the winning ratio is $20: 1$. The informed bidder values the target at \$210 million, and would bid \$200 million, with a \$10 million lockup (I represent this bid/lockup pair as 200/10), if it were bidding "honestly." If the bidder claims that its valuation is $\$ 189$ million and bids $180 / 9$, it does better on an expected basis if the odds of its bid being topped are not greater than 20/21. (This follows from solving the equation $x(30)+(1-x)(9)=10$.) Presumably, if its bid reflects a valuation below the second-highest preinvestigation estimate, that bidder will incur investigation costs to check it. As a result, bidders will be able to lowball only by a small amount.

178 See supra note 20.

179 It should be clear that this is far more pernicious, in terms of reducing returns to search, than management's ability to reject offers. Even if it were the case that hostile takeovers were essentially impossible, acquirers could seek out willing targets and profit by acquiring them. But the current structure of corporate law seems designed to thwart such a practice. The effect of the Williams Act is to impose an auction regime even on voluntary mergers, see supra note 4, and management's duty of loyalty has been interpreted to include maximizing the sale price in such auctions. See supra note 30 and accompanying text. If management is allowed to use lockups to increase the sale price, the duty of loyalty will require it to do so. The analysis in Part II shows that this technique has the potential to drive retums to search below zero; consequently, the incentives to seek out even willing targets will be drastically curtailed. 
perspective, the reactionaries are correct in their claim that second-bidder lockups should be prohibited.

The theory underlying the reactionary conclusion, however, is not correct. The reactionaries' focus on hostile acquisitions misleads them. Lockups are a bad defensive device: because their use triggers a duty to auction, management wishing to retain tenure will simply reject hostile offers. Understanding that lockups are not used this way produces different conclusions in different circumstances. In the bankruptcy context, search is virtually costless and there are good reasons to promote the goal of increasing returns to creditors. Since lockups, in the hands of competent management, will have this effect, bankruptcy presents a situation in which all lockups should be enforced, subject only to the business judgment rule. 
